
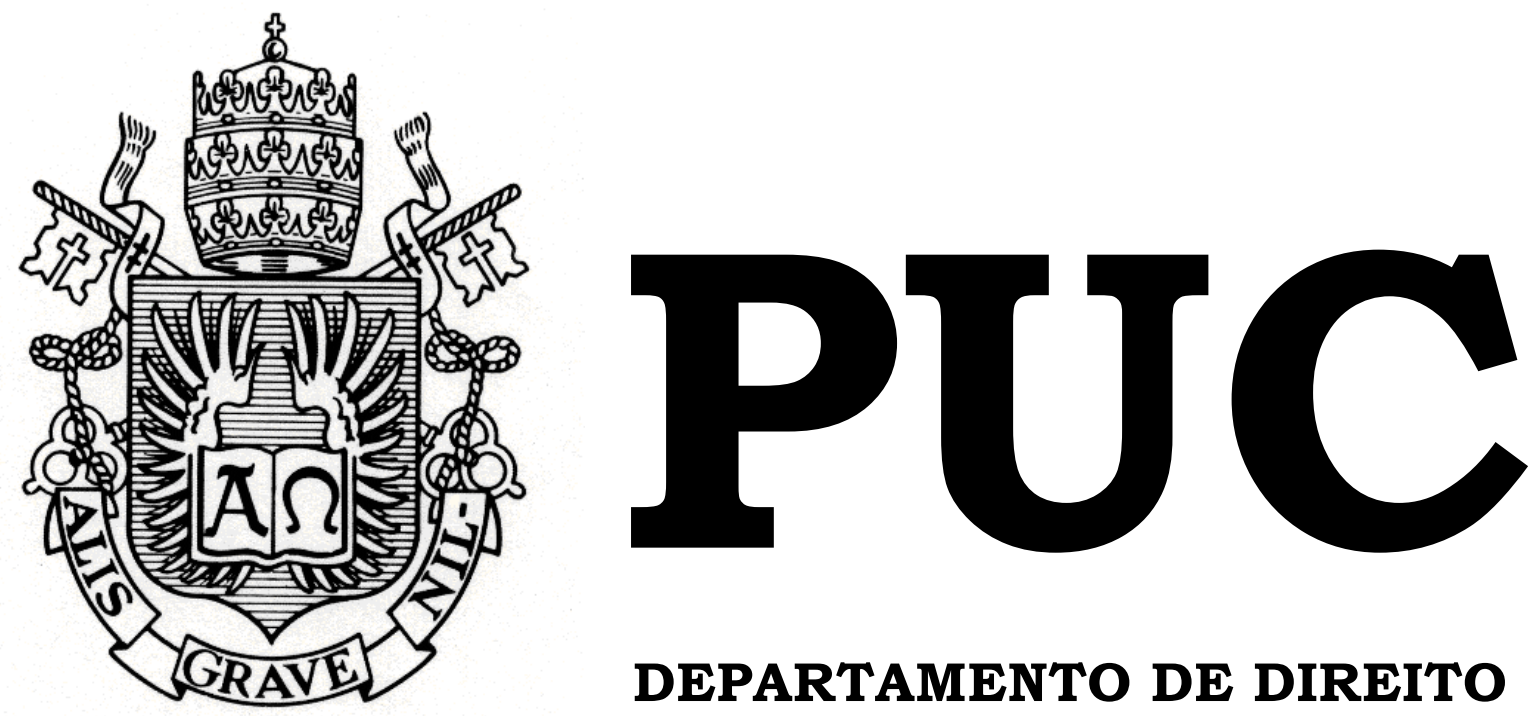

DEPARTAMENTO DE DIREITO

Privação de liberdade e seus reflexos nas crianças que nascem no cárcere: uma análise da LEP à luz dos Direitos Humanos

$$
\text { por }
$$

Maira Miranda Fattorelli

Orientadora: Bethania Assy

Coorientadora: Victoria de Sulocki

2014.2

PONTIFÍCIA UNIVERSIDADE CATÓLICA DO RIO DE JANEIRO RUA MARQUÊS DE SÃO VICENTE, 225 - CEP 22453-900 RIO DE JANEIRO - BRASIL 


\title{
Privação de liberdade e seus reflexos nas crianças que nascem no cárcere: uma análise da LEP à luz dos Direitos Humanos
}

\author{
por
}

Maira Miranda Fattorelli

Monografia apresentada ao Departamento de Direito da Pontificia Universidade Católica do Rio de Janeiro (PUC-Rio) para a obtenção do Título de Bacharel em Direito.

Orientadora: Bethania Assy

Coorientadora: Victoria de Sulocki 
Aos meus pais, pelo despertar crítico e, principalmente, por todo amor, carinho e apoio;

À Alice e à Ana, pela lembrança da criança que sempre vive em nós e pela alegria de cada dia;

Aos meus avós, por todo afeto e pelo mais doce colo.

Ao Gabriel, paz do meu sorriso, pela sintonia e pelo amor mais sincero. 


\section{Agradecimentos:}

Às minhas orientadoras, Bethania e Victoria, pelo apoio essencial e por todo crescimento que me proporcionaram ao longo da graduação.

Ao Núcleo de Direitos Humanos da PUC-Rio, pelas oportunidades e por toda aprendizagem, local único e precioso em nosso departamento.

Ao Núcleo de Defesa dos Direitos Humanos da Defensoria Pública do Rio de Janeiro e ao defensor público Henrique Guelber, por despertarem minha sensibilidade e indignação frente à realidade de nosso sistema prisional.

À Maíra Fernandes, pelo acolhimento do tema e pela esperança de efetivação do trabalho.

Às amigas irmãs e aos amigos do peito, que acreditando e incentivando deram apoio fundamental aos desafios vividos durante a graduação.

Especialmente ao meu pai, por orientar e incentivar os trabalhos acadêmicos realizados ao longo destes cinco anos e ao Gabriel, pelas inúmeras conversas, leituras e apoio. Meu muito obrigada por toda generosidade e carinho. 
"Um menino nasceu - o mundo tornou a começar." João Guimarães Rosa. Grande sertão: veredas. 


\section{Resumo:}

O presente trabalho, partindo da análise da realidade do nosso sistema penitenciário, debruça-se sobre a condição das crianças que nascem no cárcere, filhas das mulheres que estão cumprindo pena privativa de liberdade. Considerando a opção da Lei de Execução Penal pela permanência destas crianças no presídio, na companhia de suas genitoras, o trabalho abordará as consequências que esta estadia é capaz de provocar nos infantes de tenra idade que acabam compartilhando com suas mães as angústias próprias da privação de liberdade.

Após serem verificadas as especificidades atreladas à maternidade encarcerada, serão enaltecidos os direitos das crianças e das mulheres nos períodos de gestação e amamentação, no intuito de contrastá-los com a experiência vivenciada nos presídios. Serão delineadas, deste modo, todas as implicações jurídicas, sociais e psicológicas que a vivência maternal no meio carcerário é capaz de provocar, a fim de que se possa anunciar novos caminhos jurídicos, capazes de melhor equacionar os direitos das crianças e mulheres com o interesse do Estado no exercício do ius puniendi penal. Deste modo, pretende-se contribuir para uma harmonização de nosso ordenamento jurídico pátrio com as disposições firmadas no âmbito do direito internacional dos direitos humanos. 


\section{Palavras-Chave:}

Cárcere

Sistema Prisional

Maternidade

Criança

Mulher

Direitos Humanos

Direitos da Criança

Lei de Execução Penal

Estatuto da Criança e do Adolescente 


\section{Sumário:}

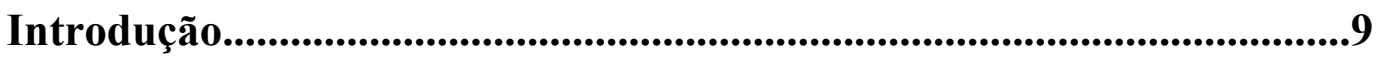

\section{Primeiro Capítulo: Cárcere e direitos humanos}

1.1. Direitos humanos: ausência e potencialidade.......................................12

1.2. O sistema carcerário em perspectiva.....................................................14

1.3. O cárcere como não-lugar dos direitos humanos...................................17

Segundo Capítulo: A problemática das crianças que nascem no cárcere

2.1. Particularidades da mulher na prisão...................................................22

2.2. A experiência da maternidade na Unidade Materno Infantil.................27

Terceiro Capítulo: Viabilidade jurídica da permanência de crianças no cárcere

3.1. Normativa de proteção da criança e prospectivas do Direito

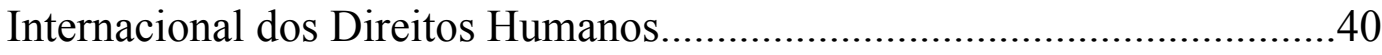

3.2. A incompatibilidade da norma penal brasileira com o princípio do interesse superior da criança .47

Quarto Capítulo: A prisão domiciliar como medida necessária para garantir o melhor interesse da criança

4.1. Priorização dos direitos da criança sobre os demais direitos em

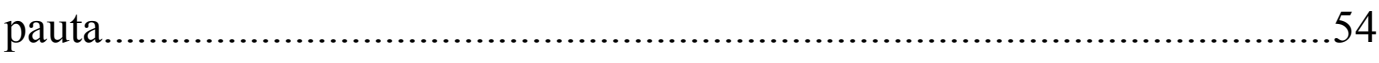

4.2. Breve panorama legal da América Latina.............................................61

4.3. Avanços verificados na jurisdição interna...............................................65

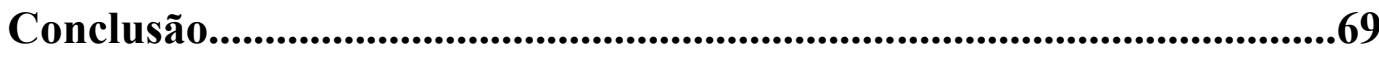

Referências Bibliográficas.......................................................................72 


\section{Lista de Abreviações:}

CEPRJ - Centro Estadual de Estatísticas, Pesquisas e Formação de Servidores Públicos do Rio de Janeiro

CIDH - Comissão Interamericana de Direitos Humanos

CNJ - Conselho Nacional de Justiça

CNPCP - Conselho Nacional de Política Criminal e Penitenciária

Corte IDH - Corte Interamericana de Direitos Humanos

ECA - Estatuto da Criança e do Adolescente

LEP - Lei de Execução Penal

OC - Opinião Consultiva

ONU - Organização das Nações Unidas

PNUD - Programa das Nações Unidas para o Desenvolvimento

SEAP - Secretaria de Administração Penitenciária

SOE - Serviço de Operações Externas

UMI - Unidade Materno Infantil

UNICEF - Fundo das Nações Unidas para a Infância 


\section{Introdução:}

A diversidade social e cultural encontrada em nosso país, marca de riqueza e potencial, parece ser desprezada pelo poder público, que ao longo das décadas tem firmado posicionamento no sentido de estigmatizar e inferiorizar nossa pluralidade. Os movimentos sociais e as desigualdades de classe, neste contexto, despontam como alvo do poder punitivo penal, que em nome da ordem e da segurança pública tem insistido em um encarceramento sistemático da pobreza ${ }^{1}$. O Estado, deste modo, muitas vezes acaba por considerar seus cidadãos apenas a partir de uma perspectiva criminal, disponibilizando às classes marginalizadas, no lugar de sérias políticas sociais e culturais, vagas no inchado sistema prisional.

A partir do desenvolvimento desta política penal estéril e inapropriada, atesta-se um crescimento exponencial de nossa população carcerária, que hoje já representa a quarta maior do mundo, estando atrás apenas dos Estados Unidos, China e Rússia ${ }^{2}$. Renato de Vitto, diretor-geral do Depen, afirma acerca da problemática que "o superencarceramento encontrou no Brasil um solo extremamente fértil"”. Com um déficit de mais de duzentas mil vagas ${ }^{4}$, nosso sistema penitenciário apresenta condições inumanas de vida, sendo considerado um verdadeiro depósito de corpos.

As violações de direitos humanos vislumbradas no interior de nossos presídios não podem ser ignoradas e é imperioso, neste sentido, que se avaliem as reais consequências que estas importam para nosso Estado Democrático de Direito. Nossa sociedade, intitulada protetora dos direitos fundamentais, não pode passar ao largo de um profundo debate acerca das

\footnotetext{
1 BATISTA, Vera Malaguti. Adeus às ilusões, p. 5. Disponível em: https://www.academia.edu/4554263/Adeus_as_ilusoes. Acesso em: 30/10/14.

${ }^{2}$ CNJ. Novo diagnóstico de pessoas presas no Brasil, de junho de 2014, p. 15. Disponível em: http://www.cnj.jus.br/images/imprensa/pessoas_presas_no_brasil_final.pdf. Acesso em: 30/10/14. ${ }^{3}$ VITTO Renato de. In: RECONDO, Felipe. Prisões batem novo recorde de lotação. JusBrasil, 2014. Disponível em: http://temistoclestelmo.jusbrasil.com.br/noticias/147934768/prisoes-batemnovo-recorde-de-lotacao. Acesso em: 01/11/14.

${ }^{4}$ CNJ. Op cit., p. 6.
} 
implicações que a realidade de vida intramuros importa para o alcance de uma verdadeira democracia comprometida com os direitos humanos.

Atentando-se o olhar para nossos presídios se evidencia o estado de profunda vulnerabilidade que recai sobre seus internos. Longe das condições inerentes à vida digna, nossos presidiários convivem com a dor do esquecimento e da invisibilidade. Nos interiores dos muros prisionais realidades à parte são encontradas, muitas delas jamais imaginadas. Dentre elas, destaca-se uma situação limítrofe, que envolve diversos fatores sociais e jurídicos e que apresenta uma vulnerabilidade ainda maior. Trata-se da situação enfrentada pelas crianças que nascem no cárcere. Os filhos das apenadas convivem com estas no interior de nossos presídios, compartilhando todas as mazelas que o sistema prisional pode oferecer.

Nossa legislação de execução penal, ao versar sobre o tema, optou pela permanência das crianças no cárcere, durante os seus primeiros meses ou anos de vida, no intuito de garantir a primordial relação entre mãe e filho, que deve ser desenvolvida nos estágios iniciais de vida. O legislador pátrio, no entanto, parece ter se esquivado de considerar todas as implicações que a estadia no interior dos muros das penitenciárias brasileiras, que apresentam condições notoriamente opostas às exigidas na lei, seriam capazes de provocar nas crianças de tenra idade que nele vivenciam seus primeiros contatos e desenvolvimentos com o mundo.

Partindo desta inquietação, o presente trabalho pretende abordar todos os aspectos relacionados com a estadia das crianças no cárcere, identificando seus limites, possibilidades e, ainda, analisando todos os reflexos sociais, psicológicos e jurídicos que a temática é capaz de provocar. Nosso olhar, deste modo, se voltará para o universo materno e infantil intramuros, descobrindo suas necessidades e anseios.

O primeiro capítulo abordará o cárcere de maneira ampla, delimitando seu surgimento e o papel que o instituto prisional ocupa na sociedade atual, chamando atenção às violações de direitos humanos e para o processo de esvaziamento subjetivo inerente à privação de liberdade. 
Após serem delineadas as intempéries associadas ao cumprimento de pena se passará a apreciar as especificidades das mulheres encarceradas, atentando-se, no segundo capítulo, às temáticas de gênero que devem ser destacadas no intuito de compreender-se, de forma ampla, o cumprimento da pena privativa de liberdade por uma mulher. Neste sentido, será chamada a atenção ao exercício da maternidade, uma das situações mais caras para as mulheres encarceradas, ressaltando-se momentos importantes, que diferem o exercício da maternidade vivenciado dentro e fora dos limites prisionais. O período de acompanhamento médico pré-natal, o parto e o momento da separação entre mães e bebês - atestado quando as crianças deixam o cárcere - serão explorados a partir da realidade da Unidade Materno Infantil, localizada no Complexo Gericinó, em Bangu, escolhido como universo da pesquisa. $\mathrm{O}$ tema será visto a partir da visão das próprias internas e de especialistas como psicólogos, assistentes sociais e juristas.

O terceiro capítulo versará sobre os direitos da criança e da mulher nos períodos de gestação e amamentação, sublinhando a especial proteção que a eles deve ser concedida por parte do Estado e da sociedade. O tema será abordado a partir do plano do direito internacional dos direitos humanos, a fim de identificar-se os standards internacionais e, após, contrastá-los com a experiência do aprisionamento infantil, verificando-se todas as violações de direitos que esta prática é capaz de provocar.

Por fim, no quarto e último capítulo do desenvolvimento, atentar-seá a novos caminhos jurídicos, capazes de compatibilizar o interesse do Estado no cumprimento da pena por parte da mulher que cometeu um delito e os direitos das crianças e das mulheres no exercício da maternidade. Será apresentada, então, uma solução apontada no direito internacional e implementada no direito comparado, que elenca a prisão domiciliar da mulher enquanto mãe como a melhor saída para equacionar os direitos em pauta, priorizando o interesse superior infantil e harmonizando nosso ordenamento jurídico com as diretrizes firmadas no plano internacional dos direitos humanos. 


\section{Primeiro Capítulo: Cárcere e direitos humanos}

\subsection{Direitos humanos: ausência e potencialidade:}

Presencia-se, a partir do contexto instaurado após a Guerra Fria, uma trajetória de afirmação dos direitos humanos, evidenciada a partir da consolidação de uma consciência humanitária, da efervescente formulação de tratados e convenções internacionais de proteção do homem e da humanização das constituições nacionais. Nesta perspectiva, os direitos humanos parecem despontar como um símbolo unificador da sociedade contemporânea, sendo capazes de convergir, ainda que de forma superficial, interesses antagônicos, aspirações políticas, o norte e o sul. Conforme indica Costas Douzinas, "vivemos em uma cultura dos direitos humanos"5.

Entretanto, apesar de concebidos enquanto elemento de crítica e de emancipação do homem, os direitos humanos, na medida em que não estão atrelados a conceitos determinados, também podem ser mobilizados como mecanismo capaz de legitimar as relações de força e de dominação que teriam, inicialmente, se proposto a atacar. Nessa conjuntura, Douzinas chama atenção para os paradoxos circunscritos aos direitos humanos, que seriam hábeis a desvirtuar seus reais e genuínos propósitos.

Em meio a esta percepção, verificam-se situações fáticas capazes de corroborarem os questionamentos lançados sobre os direitos humanos. Ao representarem a negação de direitos e a absoluta ausência de efetividade das normas positivas, certas situações se mostram capazes de colocar em colapso toda a teoria humanística formalmente concebida. As violações de direitos humanos, longe de figurarem como exceção, ditam vidas e parâmetros sociais. Convive-se hoje no Brasil com bolsões que parecem desconhecer as normas mais basilares e universais de direitos humanos.

\footnotetext{
${ }^{5}$ DOUZINAS, Costas. O fim dos direitos humanos. São Leopoldo: Unisinos, 2009, p. 253.
} 
Esta contradição teórico-concreta pode ser compreendida a partir do reconhecimento da abstrativização que recai sobre o sujeito das normas de direitos humanos, ou seja, da identificação de que o "humano" dos direitos humanos pode representar uma indeterminação inalcançável. Indeterminação esta que pressupõe a inexistência de um sentido único e pré-fixado para o destinatário das normas humanitárias. Constata-se, nestes termos, que estas podem acabar por distanciar-se dos sujeitos concretos que clamam por proteção. Nas palavras de Douzinas:

O sujeito jurídico, o conceito-chave sem o qual os direitos não podem existir, é, por definição, altamente abstrato, uma estrutura ou esqueleto que será preenchido com a carne fraca dos deveres e o sangue desbotado dos direitos. A metafísica jurídica não tem tempo para a dor das pessoas reais. ${ }^{6}$

Diante deste cenário depreende-se, como aponta Boaventura de Sousa Santos, a fragilidade dos direitos humanos enquanto gramática da dignidade humana ${ }^{7}$. A distância da prática em relação à teoria positiva faz com que uma grande contradição coloque em xeque nossa definição de sociedade intitulada democrática e protetora dos direitos fundamentais. Assevera o autor que "a grande maioria mundial não é sujeito de direitos humanos. É objeto de discursos de direitos humanos"8. Deste modo, o arcabouço teórico de proteção do homem, conquistado com o suor das revoluções, é desafiado e clama pela identificação da real implicação que a tolerância às violações de direitos humanos podem ocasionar.

Frente à nossa realidade, nos deparamos com situações de fato que despertam inquietude e perplexidade ao revelarem a falência acima anunciada. Dentre elas, merece destaque o cotidiano dos 567.655 cidadãos brasileiros que se encontram cumprindo pena em nosso sistema

\footnotetext{
${ }^{6}$ Ibid., p. 262.

${ }^{7}$ SANTOS, Boaventura de Sousa. Se Deus Fosse um Activista dos Direitos Humanos. Coimbra: Edições Almedina, S.A., 2013, p. 8.

${ }^{8}$ Ibid., p. 13.
} 
penitenciário, disputando por espaço, colchões e dignidade, na medida em que este tem capacidade para abrigar apenas 357.219 de nossos apenados ${ }^{9}$.

Concentrar o olhar sobre nossos presídios nos faz descobrir um mundo à parte, onde as subjetividades são desbotadas, as capacidades políticas são dissolvidas e as carências mais generalizadas são evidenciadas. Um processo de acentuada vulnerabilidade, nestes termos, é firmado sobre nossos detentos, que usualmente são tratados como seres com humanidade reduzida, como o excedente de uma sociedade comprometida com a afirmação dos direitos humanos. O presídio, conforme observa Michel Foucault, é o local da negação de todo o direito rea ${ }^{10}$.

\subsection{O sistema carcerário em perspectiva:}

$\mathrm{O}$ nascimento dos estabelecimentos prisionais, historicamente associado ao abandono das penas cruéis, marca um suposto processo de humanização das penas. Na passagem do século XVIII para o XIX, as penas de açoite, de morte e de destruição de corpos, traduzidas pela violência e pela lógica do espetáculo, são substituídas pela pena de detenção, que passa a ser vista como a "pena das sociedades civilizadas" Nas palavras de Foucault, a prisão "marca um momento importante na história da justiça penal: seu acesso à 'humanidade"” 12 .

Tendo como base a liberdade inerente a cada indivíduo, principal bem jurídico da sociedade capitalista industrial, a prisão surge como expressão da pena proporcional e adequada, quantificada em dias-salário, com exata conotação temporal e econômica. Em virtude de sua clareza jurídica, a pena privativa de liberdade passa a compor o centro do sistema penal. Assim, ainda nos termos de Foucault, "como não seria a prisão a

\footnotetext{
9 CNJ. Op. cit., p. 17.

${ }^{10}$ FOUCAULT, Michel. Ditos e Escritos IV. Rio de Janeiro: Forense Universitária, 2010, p. 9.

${ }^{11}$ Id., Vigiar e punir. Petrópolis: Editora Vozes, 1977, p. 218.

${ }^{12}$ Ibid., p. 217.
} 
pena por excelência numa sociedade em que a liberdade é o bem que pertence a todos da mesma maneira e ao qual cada um está ligado por um sentimento 'universal e constante'?"13.

A liberdade, nesse contexto, encontra-se relacionada com a noção de responsabilidade individual e o delito, compreendido a partir da teoria contratualista, apresenta-se como uma violação ao pacto social. Por conseguinte, o desvirtuamento da ordem demandaria a imposição de uma pena capaz de coibir a liberdade individual transgressora. Assim, conforme dispõe Pedro Abramovay, é firmado o dogma, ainda hoje presente, da pena enquanto solução para a conflitividade social. Nas palavras do autor, "a consciência de que cada indivíduo é livre e, portanto, responsável pelos seus atos constitui o arcabouço teórico pelo qual a pena, por si só, consegue criar um desestímulo em cada indivíduo, inibindo-o a cometer delitos" ${ }^{14}$.

O presídio, no entanto, longe de humanizar, foi evidenciado, desde a sua concepção, como um mecanismo de controle. Impulsionado por um modelo econômico ganancioso, ele visa o esvaziamento político de seus internos. Nessa esteira, a instituição carcerária, ao invés de representar uma democratização da pena, afigura-se, ainda que inicialmente de forma mascarada, como um aparelho capaz de criar figuras preordenadas, anêmicas, alvos fáceis do controle dominante. Indica Foucault:

O fracasso da prisão foi imediato e registrado quase ao mesmo tempo que o seu próprio projeto. Desde 1820, constata-se que a prisão, longe de transformar os criminosos em pessoas honestas, só serve para fabricar novos criminosos, ou para enterrar ainda mais os criminosos na criminalidade. ${ }^{15}$

O fundamento social do presídio, ao lado do conceito de pena privativa de liberdade, encontra-se imerso em crises e obsoletismos. O dogma da pena e seu propósito ressocializador representam apenas a fachada de uma sólida construção por dominação, fundada na

\footnotetext{
${ }^{13}$ Ibid., p. 219.

${ }^{14}$ ABRAMOVAY, Pedro Vieira. O grande encarceramento como produto da ideologia (neo)liberal. In: Depois do Grande Encarceramento. Rio de Janeiro: Editora Revan, p. 14.

${ }^{15}$ FOUCAULT, Michel. Ditos e Escritos IV. Op. cit., p. 162.
} 
desqualificação política do indivíduo encarcerado. Vera Malaguti, neste sentido, afirma que "através do discurso de recuperação, da 'ressocialização e da reeducação', o que se percebe são os objetivos bem claros: medidas de contenção social elaboradas com critérios bem explícitos na sua seletividade" ${ }^{\prime 16}$. Sublinha-se, nesses termos, a noção enunciada por Foucault da prisão enquanto instituto perigoso e inútil ${ }^{17}$.

Apesar da criminologia crítica ter estabelecido um consenso, desde 1970, corroborando a falência do sistema penitenciário e determinando a ausência de legitimidade deste enquanto solução para a conflitividade social $^{18}$, a prisão continua ocupando espaço central em nosso sistema penal. Para justificar este instituto insustentável, nossas autoridades recorrem ao postulado da segurança pública, inserido nos discursos de lei e ordem.

Assiste-se, nesse contexto, a substituição da liberdade em prol da segurança e da dignidade em prol da ordem, em um espetáculo social confeccionado de modo a dar conta do medo produzido pelas agências de comunicação, que forjam a assimilação entre o criminoso e a desestruturação social. Como indica o autor Loïc Wacquant, a segurança pública é executada com o intuito de ser exibida, teatralizada, promovendo o discurso da ordem e a ânsia social pela repressão criminal.

(A) nova gestão da lei-e-ordem transforma a luta contra o crime em um titilante teatro burocrático-midiático que, simultaneamente, sacia e alimenta os fantasmas da ordem do eleitorado, reafirma a autoridade do Estado através de sua linguagem e de sua mímica viris, e erige a prisão como o último baluarte contra as desordens, que, irrompendo de seus porões, são vistas como capazes de ameaçar os próprios fundamentos da sociedade. ${ }^{19}$

Agregado ao valor da segurança pública encontra-se um processo de encarceramento e de negação de direitos que recai sobre uma parcela específica da população: o inimigo do direito penal. Trata-se de um

\footnotetext{
${ }^{16}$ BATISTA, Vera Malaguti. Difíceis ganhos fáceis: drogas e juventude pobre no Rio de Janeiro. Rio de Janeiro: Instituto Carioca de Criminologia/Revan, 2003, p. 130.

${ }^{17}$ FOUCAULT, Michel. Vigiar e punir. Op. cit., p. 218.

${ }_{18}^{18}$ BATISTA, Vera Malaguti. Adeus às ilusões. Op. cit., p. 1.

${ }^{19}$ WACQUANT, Loïc. Punir os pobres. Rio de Janeiro: Editora Revan, 2007, p. 11.
} 
conceito aberto, que ao longo de nossa conjuntura histórico-política vem sendo preenchido com diferentes grupos sociais, como os capoeiras, os subversivos políticos ou os manifestantes. Em todos os casos, como principais critérios de seleção temos a classe social e a cor da pele.

Em desfavor do inimigo a sociedade suporta, e por vezes até mesmo clama, pela ausência dos direitos humanos. Contra ele a marginalização é desejada e o processo de redução de humanidade naturalizado. Conforme preleciona Zaffaroni, "a essência do tratamento diferenciado que se atribui ao inimigo consiste em que o direito lhe nega sua condição de pessoa"20.

Os internos de nosso sistema penitenciário apresentam-se, nessa ótica, como inimigos ao invés de pessoas. Para eles não se adequam as garantias constitucionais e a "civilização" da sociedade contemporânea. Ainda nos dizeres do autor argentino, aos inimigos "é negado o direito de ter suas infrações sancionadas dentro dos limites do direito penal liberal, isto é, das garantias que hoje o direito internacional dos direitos humanos estabelece universal e regionalmente" ${ }^{21}$.

Deste modo, se atesta que a norma abstrata dos direitos humanos pode não alcançar o meio carcerário, fazendo com que no interior de seus muros desenvolva-se uma normativa de fato, baseada na violência e na dominação, que passe a ditar a vida de nossos detentos.

\subsection{O cárcere como não-lugar dos direitos humanos:}

Despontando o presídio como o local próprio do "outro" 22 , daquele que rompe com o pacto e que instaura a desordem social, nele são atestadas as mais severas violações de direitos fundamentais, sem que estas importem em um maior questionamento acerca de seus efeitos ou significados. Nossa estrutura hegemônica de proteção dos direitos humanos e nosso Estado

\footnotetext{
${ }^{20}$ ZAFFARONI, E. Raúl. O inimigo no direito penal. Rio de Janeiro: Editora Revan, 2007, p. 18.

${ }^{21}$ Ibid., p. 11.

22 "Outro" utilizado como o marginalizado, o inimigo delineado por E. Raúl Zaffaroni.
} 
Democrático de Direito não parecem, a priori, serem abalados pelas violações observadas cotidianamente no cárcere. Afinal, estas fariam parte da lógica impulsionada pelo paradigma da segurança pública, que se proporia à dominação e reformulação subjetiva dos indivíduos considerados pelo sistema penal como criminosos e ameaçadores da ordem.

Entretanto, o contexto de violência sistêmica e o acentuado número de mortes e de casos de tortura evidenciados no meio carcerário não podem passar despercebidos. Tendo sido demonstrado que no ano de 2013 houve uma média de uma morte a cada dois dias em nossas prisões ${ }^{23}$, compreende-se que nelas são verificadas verdadeiras chacinas, que violam frontalmente a garantia dos direitos à vida e à dignidade.

Situações limítrofes, porém frequentes, fizeram com que o Sistema Interamericano de Direitos Humanos concedesse, em razão das violações de direitos verificadas nos presídios brasileiros, diversas medidas provisórias e cautelares em favor de nossos apenados. Dentre elas, vale destacar a medida provisória concedida aos internos de Urso Branco - local em que foi atestada a morte de mais de cem detentos entre 2000 e 2007 - e a medida cautelar deferida aos internos da Penitenciária de Pedrinhas, onde cerca de quarenta internos faleceram apenas no ano de $2013^{24}$.

Ao lado do desprezo à vida, constata-se em nossos presídios irregularidades relacionadas à ausência de privacidade, salubridade, iluminação, escassez de materiais de higiene e limpeza, precário atendimento médico e dentário, insuficiente atendimento jurídico, escolar e profissionalizante, péssima qualidade alimentar, dentre outras. Nesses termos, se evidencia que as precárias condições carcerárias, ao lado da superpopulação - problema crônico que agrava as mazelas concorrentes -,

\footnotetext{
${ }^{23}$ CARAZZAI, Estelita Hass e CAMPANHA, Diogenes. Prisões brasileiras registram uma morte a cada dois dias. Folha de São Paulo online. Disponível em: http://www1.folha.uol.com.br/cotidiano/2014/01/1395204-prisoes-brasileiras-registram-umamorte-a-cada-dois-dias.shtml. Acesso em: 21/07/14.

${ }^{24}$ Corte IDH. Medida Provisória. Caso da Penitenciário Urso Branco; CIDH. Medida Cautelar. Caso do Complexo Penitenciário de Pedrinhas. Disponíveis em: http://www.oas.org/pt/. Acesso em: 29/09/2014. Ver também: http://www.cnj.jus.br/noticias/cnj/28812:relatorio-do-cnj-cobraprovidencias-para-frear-mortes-no-presidio-urso-brancoro. Acesso em: 29/09/2014.
} 
são responsáveis pela inviabilidade da vida digna no cárcere ${ }^{25}$. Conforme demonstram os autores Maria Lucia Karam e Sacha Darke:

\begin{abstract}
Danos e dores são inerentes à privação da liberdade: a limitação do espaço, a impossibilidade de ir a outros lugares, de buscar e estar com quem se deseja; o isolamento, a separação, a distância do meio familiar e social; a perda de contato com experiências normais de vida; a falta de ar, de sol, de luz; a promiscuidade dos alojamentos; a precariedade das condições sanitárias; a falta de higiene; a alimentação muitas vezes deteriorada; a convivência forçada; a disciplina e a submissão; a vigilância permanente; os regulamentos que devem ser obedecidos sem explicações nem possibilidades de questionamento; o sistema de regalias que transforma direitos em recompensas por comportamentos tidos como bons. ${ }^{26}$
\end{abstract}

Nosso sistema penitenciário, deste modo, é erguido como o local por excelência de violação de direitos e de abandono de corpos. Abrigando nossa crescente massa carcerária, que já passa da casa dos quinhentos e cinquenta mil internos, ele acentua a marginalização e a invisibilidade de sujeitos que historicamente encontram-se no limite da proteção dos direitos constitucional e internacional. Conforme afirma Nilo Batista, "muita pena sinaliza pouco oxigênio democrático, sinaliza autoritarismo" ${ }^{27}$ e estas penas, ao associarem-se à violência e repressão, nos remetem aos sórdidos períodos ditatoriais e nos fazem presenciar, nas palavras de João Ricardo Dornelles, "um passado obscuro que reaparece no presente"28.

Ao tolerar e institucionalizar a violência para com o "outro", o criminoso, nosso país se insere num contexto latino-americano marcado por um conturbado processo de justiça transicional. Nossa máquina estatal apresenta-se, principalmente do ponto de vista penal, mergulhada em um duplo regime, que mistura teoria democrática com prática ditatorial.

\footnotetext{
${ }^{25}$ Ressaltamos o contraste da anunciada realidade prisional com as Regras Mínimas para o Tratamento dos Reclusos das Nações Unidas, aprovadas em 1955 através das resoluções 663C (XXIV) do Conselho Econômico e Social.

${ }^{26}$ DARKE, Sacha e KARAM, Maria Lucia. Administrando o cotidiano da prisão no Brasil. In: Discursos Sediciosos, Ano 17. Números 19-20. Instituto Carioca de Criminologia. Rio de Janeiro: Editora Revan, 2012, p. 406/407.

27BATISTA, Nilo. In: Revista Poli. Entrevista: Nilo Batista - 'Muita Pena sinaliza pouco oxigênio Democrático, sinaliza autoritarismo'. Edição n. 29, de jul/ago. 2013. Disponível em: http://www.epsjv.fiocruz.br/upload/EdicoesRevistaPoli/R36.pdf. Acesso em: 20/07/14.

${ }^{28}$ DORNELLES, João Ricardo W. Direitos humanos, violência e barbárie no Brasil: uma ponte entre o passado e o presente. In: Direitos humanos: justiça, verdade e memória. Rio de Janeiro: Lumen Iuris, 2012, p. 435.
} 
Apesar de notória a inadequação entre nossos estabelecimentos prisionais e a Lei de Execução Penal, e ainda que os relatórios de monitoramento carcerário apontem unanimemente a incompatibilidade do cárcere com o fundamento republicano da dignidade da pessoa humana, nossos juízes permanecem condenando diariamente dezenas de pessoas ao cumprimento de pena privativa de liberdade. No momento da fixação desta, no entanto, não é contabilizado o reflexo social e pessoal que invariavelmente esta pena imporá ao condenado.

Diante da negação dos direitos humanos no meio penitenciário se compreende que este deixa de ser um simples espaço de reclusão e, na medida em que passa a ser regido por uma norma própria, constituída nas dinâmicas de fato, insere-se no conceito de estado de exceção desenvolvido por Giorgio Agamben. De acordo com o autor, no estado de exceção a norma jurídica encontra-se suspensa, por decisão do soberano, para que o ordenamento jurídico seja resguardado. Trata-se de uma exclusão, atestada para que a integridade da norma positiva não venha a ser abalada. Assim, no estado de exceção encontra-se a vigência da norma jurídica por meio da determinação de sua não incidência. Nas palavras de Agamben:

\begin{abstract}
A exceção é, no direito, um elemento que transcende o direito positivo, na forma da sua suspensão. (....) A exceção é uma espécie de exclusão. Ela é um caso singular, que é excluído da norma geral. Mas o que caracteriza propriamente a exceção é que aquilo que é excluído não está, por causa disto, absolutamente fora de relação com a norma; ao contrário, esta se mantém em relação com aquela na forma da suspensão. A norma se aplica à exceção desaplicando-se, retirando-se desta. O estado de exceção não é, portanto, o caos que precede a ordem, mas a situação que resulta da sua suspensão. ${ }^{29}$
\end{abstract}

Embora o autor utilize o campo de concentração como o locus da exceção, o cárcere, ao apresentar-se como o local de negação de garantias fundamentais e da criação de uma normativa de fato, baseada na violência e na incompatibilidade com o ordenamento jurídico, parece também figurar como um bolsão próprio do estado de exceção.

\footnotetext{
${ }^{29}$ AGAMBEN, Giorgio. Homo Sacer: o poder soberano e a vida nua I. Belo Horizonte: Editora UFMG, 2002, p. 25.
} 
Nessa perspectiva, ao delinearmos o encarcerado como o inimigo e admitirmos sua morte e tortura, o inserimos no conceito de homo sacer, aquele que de acordo com Agamben vive a vida nua, sendo caracterizado por sua absoluta matabilidade, pela morte que não constitui homicídio ${ }^{30}$.

Privados de liberdade, de direitos e de valor, aqueles que compõem nosso inflado contingente carcerário recebem, junto com a punição penal, a tolerância da sociedade para com a violação de seus direitos e a autorização para que o Estado lhes subtraia parte de suas humanidades, reduzindo-os e pulverizando, a cada brutalidade, suas subjetividades.

Assim, partindo da certeza de que nosso sistema penitenciário precisa ser repensado, reformulado e reestruturado, de modo que as ultrapassadas ilusões "re" - reeducação, ressocialização e reintegração ${ }^{31}$ possam dar lugar a novos panoramas e anseios, é preciso que se debruce sobre os segmentos mais vulneráveis encontrados em nossas prisões, de modo a tentar apresentar perspectivas de mudanças urgentes e viáveis, que nos aproximem da até então utópica proteção das normas humanitárias.

Dentre as diversas problemáticas que precisam ser repensadas no nosso atual contexto penitenciário emerge uma questão delicada que, envolta a uma condição de acentuada vulnerabilidade, demanda atenção redobrada e cuidado especial. Trata-se da situação enfrentada pelas mulheres que experimentam a maternidade em meio ao ambiente carcerário e por seus filhos, que nascem dentro dos muros das prisões e lá passam seus primeiros meses ou anos de vida. Tais crianças, em nome da imprescindível relação mãe-bebê, têm por lei assegurado o direito de permanecerem no cárcere. Questiona-se, contudo, se esta opção legislativa é, de fato, capaz de salvaguardar os direitos das crianças e de suas mães ou se, ao contrário, se deveria analisar medidas diversas que se mostrassem mais adequadas a compatibilizar o tratamento fornecido a estas crianças e mães com os standards internacionais de proteção dos direitos humanos.

\footnotetext{
${ }^{30}$ Ibid., p. 74.

${ }^{31}$ BATISTA, Vera Malaguti. Adeus às ilusões. Op. cit, p. 1.
} 


\section{Segundo Capítulo: A problemática das crianças que nascem no cárcere}

\subsection{Particularidades da mulher na prisão:}

Em meio a um contexto social pautado pela lógica da repressão penal, verifica-se um crescimento vertiginoso da população carcerária feminina. Considerando-se que em 2000 se contava com um total de 5.345 mulheres cumprindo pena privativa de liberdade e que em 2012 este número havia passado para 35.039, observa-se um aumento de mais de $650 \%$ dos índices de encarceramento feminino em apenas doze anos ${ }^{32}$. O quantitativo de mulheres no cárcere, ainda que demasiadamente inferior ao masculino, vem ascendendo de modo a representar mais de $7 \%$ da população do sistema penitenciário nacional ${ }^{33}$.

Este crescimento, ao alterar substancialmente o gênero de nosso universo prisional, impõe o enfrentamento de novas problemáticas, que requerem um olhar diferenciado à compreensão da condição das mulheres encarceradas. Até o momento, contudo, existem poucos trabalhos, dados e políticas públicas relacionados ao tema, o que reforça a invisibilidade carcerária e nos leva a lidar com um conhecimento meramente parcial da real situação que as mulheres enfrentam em nossos presídios.

Apesar da carência de informação, estudos demonstram que as mulheres alvo de nosso sistema repressor penal obedecem a um perfil prédelineado, sendo em grande maioria jovens que possuem entre dezoito e trinta anos de idade, com baixa escolaridade e profissionalização quase

\footnotetext{
${ }^{32}$ CHERNICHARO, Luciana; PENCIERI, Aline e SILVA, Bruna. Mulheres encarceradas, seletividade penal e tráfico de drogas no Rio de Janeiro. VIII Encontro da ANDHEP, USP. São Paulo, 2014, p.1. Ver também dados atualizados do Infopen de 2012. Disponível em: http://www.cnj.jus.br/noticias/cnj/25949:sistema-carcerario-nacional-tem-apenas-15ginecologistas-para-35-mil-mulheres-presas. Acesso em: 31/10/14.

${ }^{33}$ INFOPEN. Relatório do Infopen de junho de 2011. Veiculado pelo Ministério da Justiça. Disponível em: http://portal.mj.gov.br/main.asp?View=\%7BDA8C1EA2-5CE1-45BD-AA075765C04797D9\%7D\&BrowserType=IE\&LangID $=$ pt-

br\&params $=$ itemID $\% 3 \mathrm{D} \% 7 \mathrm{~B} 14 \mathrm{~A} 64773 \%$ 2D0CFB\%2D45A4\%2DBA6F\%2DEC41D9AFE2BB $\%$ 7D\%3B\&UIPartUID=\%7B2868BA3C\%2D1C72\%2D4347\%2DBE11\%2DA26F70F4CB26\%7D. Acesso em: 31/10/14.
} 
inexistente $^{34}$. No Estado do Rio de Janeiro, mais de $73 \%$ destas jovens são presas por tráfico de entorpecentes, o que demonstra uma alteração do perfil da criminalidade feminina, já que até a década de 80 esta estava associada a delitos como o aborto, o infanticídio e a prostituição ${ }^{35}$.

A análise da inserção da mulher no presídio pressupõe, inicialmente, a consideração da temática a partir de uma perspectiva de gênero. As diferenças sociais existentes entre homens e mulheres fazem com que estas, quando encarceradas, convivam com a vulnerabilidade própria do gênero feminino, ao lado da condição inferiorizada que recai sobre os presos em geral. A Convenção Interamericana para Prevenir, Punir e Erradicar a Violência contra a Mulher reconhece, neste sentido, a condição específica de vulnerabilidade que incide sobre as mulheres privadas de liberdade $^{36}$. Mercedes Jabardo, antropóloga madrilena, ao averiguar os desdobramentos do encarceramento feminino, ressalta a análise de gênero:

\begin{abstract}
$\mathrm{Na}$ prisão a problemática das mulheres envolve dois aspectos distintos, diferentemente significativos, cuja consideração nos coloca em um ponto de partida mais compreensivo frente à realidade que nos ocupa. Estes dois aspectos estão inter-relacionados e, geralmente, não podem ser separados, eles seriam: a própria condição de mulher e a de mulher presa. Cada um destes inclui características tanto pessoais como sociais distintas, que determinam a forma de 'estar' da mulher na prisão. ${ }^{37}$
\end{abstract}

A apreciação das particularidades femininas se mostra ainda mais importante ao se considerar que o Brasil, de acordo com pesquisa realizada pelo Fórum Econômico Mundial, é um dos países com pior índice de igualdade de gênero na região latino-americana ${ }^{38}$. Esta lamentável

\footnotetext{
${ }^{34}$ GOMES, Aline. As prisões do feminino e as mulheres nas prisões: um recorte sobre a maternidade encarcerada. Niterói, 2010.111 p. Dissertação de mestrado - UFF, p. 51.

${ }^{35}$ CHERNICHARO, L.; BOITEUX, L. Encarceramento feminino, seletividade penal e tráfico de drogas em uma perspectiva feminista crítica. Laboratório de Direitos Humanos/UFRJ, p. 1.

${ }^{36}$ OEA. Convenção Interamericana para Prevenir, Punir e Erradicar a Violência contra a Mulher. Adotada em Belém do Pará, Brasil, em 09 de Junho de 1994. Art. 9. Ver também: CEJIL, Relatório sobre as Mulheres Encarceradas no Brasil. Op. cit., p. 6.

${ }^{37}$ JABARDO, Mercedes. La mujer y sus hijos en prision. IN: Eguzkilore. Número 7. San Sebastián, 1993, p. 94. Disponível em: http://www.ehu.es/documents/1736829/2169056/10+$+\mathrm{La}+$ mujer+y+sus+hijos+en+prision.pdf. Acesso em: 04/11/14. Tradução livre do espanhol.

${ }^{38}$ Fórum Econômico Mundial. Relatório e ranking do Global Gender Gap, 2013. Disponível em: http://www3.weforum.org/docs/Media/Portuguese_Gender\%20Gap_Final.pdf. Acesso em:
} 
constatação nos convida a analisar os distintos reflexos que nosso modelo penitenciário, notoriamente constituído a fim de atender à criminalidade masculina, é capaz de provocar nas mulheres aprisionadas. Nas palavras de Vanessa Nogueira Simone, promotora de justiça do Estado de Minas Gerais, “as mulheres são desconsideradas dentro da instituição penitenciária, já que o sistema, como outras esferas, se rege, fundamentalmente, por um modelo 'masculino' em que a norma se dita e se formula a partir das necessidades dos homens" ${ }^{\prime 39}$. Neste sentido, ressalta-se trecho do Relatório sobre as Mulheres Encarceradas no Brasil, produzido pelo CEJIL para a Comissão Interamericana de Direitos Humanos:

(E)ntre as violações de direitos humanos comuns aos presos e presas sob a tutela do Estado brasileiro, destacam-se subprodutos dessas violações que se agravam no universo feminino dos cárceres. São violações de gênero que ocorrem no cenário de graves violações, as quais são intensificadas no caso das mulheres, colocando-as, de forma diferenciada e específica, em risco e violando a integridade física, psíquica e emocional das mulheres que cumprem penas ou aguardam julgamento nas instituições oferecidas pelo Estado. ${ }^{40}$

No anunciado panorama, deve-se considerar, ao lado das mazelas estruturais, da superpopulação e da violência, as necessidades do gênero feminino, dentre as quais destacam-se o acesso a tratamento ginecológico e a atenção à maternidade. Nesta esteira pronuncia-se a Secretaria Especial de Políticas para as Mulheres da Presidência da República, ao indicar que "não há como tratar o encarceramento feminino de forma plena sem considerar fatores como a gravidez, a maternidade, a amamentação e a permanência da mulher presa com suas filhas e filhos nascidos dentro do cárcere"41.

01/11/14. In: CHERNICHARO, Luciana; PENCIERI, Aline e SILVA, Bruna. Op. cit., p. 4.

${ }^{39}$ SIMONE, Vanessa Fusco Nogueira. Filhos do cárcere: limites e possibilidades de garantir os direitos fundamentais dos filhos das mulheres privadas de liberdade no Brasil. Porto Alegre: Núria Fabris, 2013, p. 33.

${ }^{40}$ CEJIL, Relatório sobre as Mulheres Encarceradas no Brasil. Fevereiro de 2007, p. 6. Disponível em: http://carceraria.org.br/wp-content/uploads/2013/02/Relatório-para-OEA-sobreMulheres-Encarceradas-no-Brasil-2007.pdf. Acesso em: 01/11/14, p. 19/20.

${ }^{41}$ BRASIL. Presidência da República. Secretaria Especial de Políticas para as Mulheres. Revista do Observatório Brasil da Igualdade de Gênero. Brasília: Secretaria Especial de Políticas para as Mulheres, 2009, p. 69. Disponível em: http://www.mulheres.gov.br/mais-mulheres-nopoder/informacoes/materiais-diversos/revista_do_observatorio_bra.pdf. Acesso em: 01/11/14. 
Dentre as demandas femininas, o exercício da maternidade no âmbito carcerário merece destaque, já que de acordo Relatório do PNUD da ONU 96\% das mulheres privadas de liberdade na América Latina são mães $^{42}$. Esta expressiva estatística nos leva a questionar a repercussão que a pena é capaz de provocar nos filhos das mulheres encarceradas, principalmente naqueles que nascem durante o cumprimento de suas sanções. Nos termos firmados pelo PNUD, "a privação de liberdade da mulher com filhos ou filhas não produz impactos apenas para ela, mas também produz efeitos extensivos a estes, principalmente sobre os menores de idade (63.3 por cento)" ${ }^{\prime 43}$.

A análise deste impacto torna-se ainda mais importante na medida em que se reconhece que as mulheres alvo de nosso sistema repressor penal, via de regra provenientes de baixas classes sociais, usualmente são as únicas responsáveis pelo sustento de suas casas e pela criação de seus filhos $^{44}$. Dados fornecidos pela Fundação Nacional de Assistência aos Presos demonstram que apenas $20 \%$ dos pais responsabilizam-se por seus descendentes diante aprisionamento materno, o que vulnerabiliza os filhos das apenadas e desequilibra sua estrutura familiar ${ }^{45}$. Compreende-se, deste modo, que a apreciação da questão demanda a ponderação dos direitos das presas enquanto mães e os direitos de seus filhos, indivíduos que em nada se relacionam com os delitos praticados por suas genitoras.

Nosso legislador, ao enfrentar este delicado tema, atendendo à exigência constitucional referente à permanência das presidiárias com seus filhos durante o período de aleitamento ${ }^{46}$ e considerando a importância desta relação para o desenvolvimento infantil, optou pela manutenção das crianças no cárcere, na companhia de suas mães, durante os seus primeiros

\footnotetext{
${ }^{42}$ LOPEZ, Marcela Briseño. Garantizando los derechos humanos de las mujeres en reclusión. Instituto Nacional de las Mujeres do México e Programa das Nações Unidas para o Desenvolvimento (PNUD), 2006, p. 28. Disponível em: http://cedoc.inmujeres.gob.mx/documentos_download/100793.pdf. Acesso em: 01/11/14.

${ }^{43}$ Ibid, p. 60. Tradução livre do espanhol.

${ }^{44}$ GOMES, Aline. Op. cit., p. 50.

${ }^{45}$ CEJIL. Op. cit., p. 40.

${ }^{46}$ BRASIL. Constituição da República Federativa do Brasil de 1988. Art. 5, L.
} 
meses ou anos de vida. Esta é a disposição extraída dos artigos 83 e 89 da Lei de Execução Penal, alterada pela Lei 11.942, de maio de 2009.

Art. 83, $\S 2^{\circ}$ : Os estabelecimentos penais destinados a mulheres serão dotados de berçário, onde as condenadas possam cuidar de seus filhos, inclusive amamentálos, no mínimo, até 06 (seis) meses de idade. ${ }^{47}$

Art. 89: Além dos requisitos referidos no art. 88, a penitenciária de mulheres será dotada de seção para gestante e parturiente e de creche para abrigar crianças maiores de 6 (seis) meses e menores de 7 (sete) anos, com a finalidade de assistir a criança desamparada cuja responsável estiver presa. ${ }^{48}$

A LEP, nestes termos, determina a criação de berçários e creches nas unidades penais femininas e prevê a permanência dos filhos das detentas gestantes no cárcere pelo período de seis meses, para amamentação, indicando que esta estadia pode prolongar-se até os sete anos da criança, na hipótese desta não ter outra pessoa, além da mãe, para responsabilizar-se por ela. O período de permanência, no entanto, longe de ser pautado pela diretriz legal, segue padrões próprios em cada Estado, a depender da estrutura física dos presídios e, muitas vezes, da determinação dos diretores dos estabelecimentos prisionais. Analisando esta contradição e nossas disposições legais, Vanessa Nogueira Simone afirma que:

No Brasil, no âmbito normativo, a Lei de Execução Penal não trata de maneira clara a possibilidade da permanência dos filhos das reclusas na prisão e durante quanto tempo essa situação poderia ser mantida, sendo que cada Estado da Federação fixa a seu modo este período, ficando, não raras as vezes, tal tarefa a cargo do Diretor do Estabelecimento Prisional. ${ }^{49}$

Deste modo, verifica-se que o tema é abordado de forma distinta nas diferentes unidades federativas. Enquanto em Curitiba as crianças podem continuar no presídio até os seis anos, em Minas Gerais esta estadia é admitida apenas durante os dois primeiros anos de vida e, diferentemente, em Brasília e no Rio de Janeiro esta permanência é admitida tão somente

\footnotetext{
${ }^{47}$ BRASIL. Lei n. 7.210 de 11 de julho de 1984. Institui a Lei de Execução Penal, art. 83, § $2^{\circ}$.

48 Ibid., art. 89.

${ }^{49}$ SIMONE, Vanessa Fusco Nogueira. Op. cit., p. 20.
} 
durante os primeiros seis meses de vida dos bebês ${ }^{50}$. O Conselho Nacional de Política Criminal e Penitenciária, atentando à temática, editou em julho de 2009 a resolução CNPCP n. 3, que dispõe que o tempo de manutenção das crianças ao lado de suas mães nos presídios não deve ser inferior a um ano e meio, determinando, ainda, que após este lapso temporal deve ser iniciado um processo gradual de separação ${ }^{51}$.

Considerando a realidade do Complexo Gericinó - universo do trabalho, verifica-se que em seu interior o tempo de permanência dos bebês junto às suas mães mantém-se em torno de seis meses ${ }^{52}$. Em Bangu, a estadia das crianças é verificada na Unidade Materno Infantil, que conta com berçário, mas que não possui creche ou espaço adequado para crianças que ultrapassem os primeiros meses de vida. A referida Unidade, acoplada à Penitenciária Talavera Bruce, centro de referência às presas gestantes do Estado, foi construída de modo a atender às especiais exigências infantis.

\subsection{A experiência da maternidade na Unidade Materno Infantil:}

A Unidade Materno Infantil (UMI) integra o complexo Gericinó, em Bangu. Contudo, possui entrada independente, sendo acessada diretamente pela rua. Trata-se de Unidade, conforme anteriormente salientado, acoplada à Penitenciária Talavera Bruce. Uma portaria única é responsável pela

\footnotetext{
50 PRATES, Maria Clara; MELlO, Alessandra e RIZZO, Alana. Filhos do cárcere. Correio Brasiliense Online, 11 dezembro de 2011. Disponível em: http://cnj.myclipp.inf.br/default.asp?smenu=noticias\&dtlh=204957\&iABA=Not\%EDcias\&exp. Acesso em: 06/10/14.

${ }^{51}$ CNPCP. Resolução número 03, de 15 de julho de 2009, artigos 2 e 3. Disponível em: http://www.google.com.br/url?sa=t\&rct=j\&q=\&esrc=s\&source=web\&cd=1\&ved=0CB0QFjAA\& url=http $\% 3 \mathrm{~A} \% 2 \mathrm{~F} \% 2 \mathrm{Fwww}$. defensoria.sp.gov.br\%2Fdpesp $\% 2 \mathrm{FRepositorio} \% 2 \mathrm{~F} 30 \% 2 \mathrm{FDocument}$ os $\% 2$ FRESOLU $\% 25 \mathrm{C} 3 \% 2587 \% 25 \mathrm{C} 3 \% 2583 \mathrm{O} \% 2520 \mathrm{CNPCP} \% 2520 \mathrm{~N} \% 25 \mathrm{C} 2 \% 25 \mathrm{BA} \% 25203 \% 2$ C\%2520DE\%252015\%2520DE\%2520JULHO\%2520DE\%25202009\%2520mulher\%2520encarce rada\%2520e\%2520filhos.doc\&ei=HvcyVLTtCYyrggTi1YHwCw\&usg=AFQjCNEjcEimDXLQR CpEuKdt37iPZ1APew\&sig2=dDZMeQh6DXd82vfw6CNxZg\&bvm=bv.76802529,d.eXY. Acesso em: 06/10/14.

${ }^{52}$ ADADD, Cristina; SANTOS, Maricy e NASCIMENTO, Tuane. Tempo de ser mãe - reflexões sobre a experiência da maternidade no sistema prisional do Estado do Rio de Janeiro. Diásporas, diversidade, deslocamentos, 23 a 26 de 26 de agosto de 2010, p. 3. Disponível em: http://www.fazendogenero.ufsc.br/9/resources/anais/1278445643_ARQUIVO_Tempo_de_Ser_M ae.pdf. Acesso em: 01/11/14.
} 
admissão a ambas as Unidades. Todo o ritual de identificação, entrega de aparelhos celulares e submissão a aparelho detector de metal deve ser respeitado. Após a portaria, tem-se acesso a uma área aberta, que conta com uma pequena igreja ao centro, o Talavera à direita e a UMI à esquerda.

Diferentemente das demais Unidades, a UMI possui, no lugar dos altos muros com arames farpados, pequena mureta pintada com temas infantis. Em seu interior, encontra-se área destinada à direção e serviços de apoio, como assistente social e psicólogo, e dois alojamentos, com capacidade para abrigarem vinte internas e seus respectivos filhos, mobilhados com camas unidas a berços. As áreas destinadas à direção e às internas são separadas por porta e grade, na qual as presas corriqueiramente batem, clamando por comunicação com a autoridade local ${ }^{53}$.

Apesar das particularidades e da aparente leveza, a Unidade não escapa, em todo, à regra que dita os presídios em geral. $\mathrm{O}$ controle permanente, as carências emocionais e estruturais e a vulnerabilidade das internas são aspectos que continuam evidentes, ditando o dia-a-dia das mães e dos bebês. Neste sentido, Cristiana Addad e Maricy dos Santos, psicólogas da SEAP/RJ e pós-graduadas pela UERJ, afirmam que:

A Unidade Materno Infantil, portanto, não escapa ao perfil de uma instituição total, com sua rotina rígida, engessada, prefixada, onde também são investidas expectativas quanto à manifestação de comportamentos considerados desejáveis. A espontaneidade das risadas, choros e descobertas dos bebês é encompassada por uma suposta ordem que deve ser mantida e monitorável através do comportamento das mães. ${ }^{54}$

Percebe-se que embora planejada para abrigar crianças de tenra idade, a UMI está longe de despontar como ambiente ideal para o desenvolvimento sadio dos bebês que ali residem e experimentam seus primeiros momentos de vida. A influência das normas, a obediência às autoridades, a ausência de espontaneidade e, sobretudo, a carência de

\footnotetext{
${ }^{53}$ GOMES, Aline. Op. cit., p. 57.

${ }^{54}$ ADADD, Cristina; SANTOS, Maricy e NASCIMENTO, Tuane. Op. cit., p. 3.
} 
convívio com familiares e com o mundo externo fazem com que a estrutura da Unidade acabe produzindo efeitos negativos em seus pequenos internos.

Evidencia-se, neste sentido, elementos basilares que distinguem o exercício da maternidade dentro e fora dos limites do cárcere e que afetam diferencialmente as crianças que são submetidas ao denominado "encarceramento por tabela". Dentre os momentos que ganham conotação própria quando vivenciados por mulheres que se encontram cumprindo pena destaca-se i) o acompanhamento pré-natal, ii) o parto, iii) a rotina institucional do presídio e iv) a separação das mães e bebês, atestada quando estes completam os seis primeiros meses de vida.

Acerca do acompanhamento pré-natal, vale primeiramente ressaltar que este deve ser realizado na Penitenciária Talavera Bruce, eleita pela $\mathrm{SEAP} / \mathrm{RJ}$ como centro de referência às gestantes. Após o diagnóstico da gravidez, as mulheres que se encontram cumprindo pena em outras Unidades são encaminhadas ao Talavera, local teoricamente preparado para atender às exigências médicas do período gestacional.

Não se pode, todavia, deixar de evidenciar o desafio associado à garantia do direito à saúde aos internos de nosso sistema penitenciário. Apesar do Talavera ter se tornado a Unidade centralizadora de gestantes, ela não passou a contar com médico próprio ou com equipamentos especializados para garantir a realização de exames pré-natais.

Esta constatação fez com que tanto a Defensoria Pública quanto o Ministério Público tentassem intervir na problemática, encaminhando as exigências por médicos e por acompanhamento gestacional ao judiciário. As demandas judiciais foram interpostas perante a Vara de Execuções Penais no final de 2012, momento em que ambos os órgãos atestaram, de forma autônoma, o desprezo da Unidade para com a saúde das grávidas.

No Procedimento Especial apresentado pelo Núcleo do Sistema Penitenciário da Defensoria Pública, a instituição relatou a carência plena de atendimento pré-natal na Penitenciária Talavera Bruce, o que pode ser comprovado a partir do seguinte trecho extraído da peça inicial: "Pesquisa 
por amostragem realizada pela Defensoria Pública com alguma das presas grávidas mostra que $100 \%$ das 9 entrevistadas não recebe acompanhamento pré-natal. As que responderam que sim, fizeram a observação de que o acompanhamento recebido se deu antes da prisão",55.

Após a judicialização da questão, a SEAP/RJ parece ter despertado atenção à causa, tendo editado, em março de 2013, um protocolo da saúde da mulher gestante, que conta com fluxograma para nortear o atendimento pré-natal das presas grávidas. Dentre as medidas estão sete consultas, sendo três com médico do Centro Municipal de Saúde Professor Masao Goto e quatro com enfermeira da $\mathrm{SEAP}^{56}$. A louvável iniciativa da Secretaria requer, contudo, intensa fiscalização. Se o fluxograma é um enorme avanço no campo da saúde das presas grávidas, em nada ajudará se não for devidamente implementado, neste caso servindo apenas para ampliar extenso rol de direitos, que na teoria já se mostra impecável.

Ainda que não se tenha acesso a dados que demonstrem o cumprimento do plano de atendimento à saúde apresentado pela SEAP, informações fornecidos pelo Conselho Nacional de Justiça e pela direção da Penitenciária Talavera Bruce acerca da carência de médicos ginecologistas em nossos presídios instauram anseios acerca de seus resultados.

De acordo com o $\mathrm{CNJ}$, o sistema penitenciário brasileiro conta com apenas 15 médicos ginecologistas, o equivalente a um profissional para cada 2.335 mulheres ${ }^{57}$. Esta insuficiência, vislumbrada em âmbito nacional, também pode ser observada na Penitenciária Talavera Bruce, onde não há sequer um médico ginecologista que preste atendimento às internas. Acerca da referida carência, a direção local explica que "a Unidade não tem médico

\footnotetext{
${ }^{55}$ NUSPEN. Procedimento Especial apresentado pelo Núcleo do Sistema Penitenciário da Defensoria Pública do Estado do Rio de Janeiro à VEP no dia 09/11/2012. Protocolo VEP: 2012/0181213-6, p. 2. Ver também, acerca do pedido de providências realizado pelo Ministério Público do Estado do Rio de Janeiro: http://www.forumjustica.com.br/mprj-requer-medidas-paragarantir-atendimento-pre-natal-as-presas-gravidas. Acesso em: 09/10/2014.

56 SEAP/RJ. Coordenação de Gestão em Saúde Penitenciária. Saúde da Mulher - Protocolo Gestante, 2013.

${ }^{57}$ INFOPEN. Sistema carcerário nacional tem apenas 15 ginecologistas para 35 mil mulheres presas. Veiculado pelo Ministério da Justiça, dezembro de 2012. Disponível em: http://www.cnj.jus.br/noticias/cnj/25949:sistema-carcerario-nacional-tem-apenas-15ginecologistas-para-35-mil-mulheres-presas. Acesso em: 09/10/14.
} 
ginecologista ou psiquiatra porque no último concurso de títulos da CEPERJ visando preencher as vagas da Saúde da SEAP não teve candidatos para os cargos, falta de candidato, sendo que os antecessores saíram por aposentadoria ou termino de contrato anterior, ${ }^{\circ 5}$.

O anunciado quadro levou o Núcleo de Defesa dos Direitos Humanos da Defensoria Pública a ajuizar, em junho de 2014, ação civil pública a fim de garantir efetiva assistência médica às mulheres custodiadas no Estado do Rio de Janeiro. No bojo da ação há dados referentes ao Talavera Bruce, indicando que a direção deste, ao se pronunciar acerca da indagação do órgão sobre a qualidade do amparo médico fornecido pela Unidade, "apenas informou a existência de atendimento pelo ambulatório, por enfermeira, o que se diferencia por completo de atendimento médico. Informou ainda que existe um pneumologista que atende na unidade e que são realizados exames preventivos periódicos",59.

Deste modo, nota-se que até 2013 as presas grávidas de nosso Estado não recebiam, em absoluto, atendimento pré-natal. Ainda que este quadro pareça estar sendo superado, não temos como precisar a qualidade e a periodicidade do atendimento que as gestantes atualmente vêm recebendo. Imperioso se faz, neste sentido, o trabalho de fiscalização, para que se possa aferir o real acompanhamento que tem sido fornecido às gestantes do Talavera. Analisando-se o panorama ginecológico, de forma distinta, temos a certeza da até então insuficiência médica, o que demonstra um quadro de negação de direitos que urgentemente necessita ser alterado.

Passando-se à análise do parto, vale preliminarmente indicar que este deve ocorrer em hospital da rede pública próximo ao Complexo Gericinó. Uma vez identificado o início do trabalho de parto de uma interna, a direção

\footnotetext{
${ }^{58}$ SEAP/RJ. Ofício encaminhado no dia 28/03/14 pela Divisão Médico Ambulatorial da SEAP ao Núcleo de Defesa dos Direitos Humanos da Defensoria Pública do Estado do Rio de Janeiro (NUDEDH). Informação extraída do procedimento administrativo do NUDEDH E20/001/3830/2013, instaurado no dia 04/12/2013; programa: monitoramento do sistema carcerário; assunto: saúde mulheres privadas de liberdade.

${ }^{59}$ NUDEDH. Ação Civil Pública em trâmite na 4 Vara de Fazenda Pública da comarca da Capital. Protocolo: 0220470-775.2014.8.19.0001, p. 11 da peça inicial.
} 
da Unidade deve acionar o SOE - Serviço de Operações Externas -, órgão responsável por realizar o transporte da gestante até a unidade hospitalar.

Este momento, considerado único e de vital importância para as mães, muitas vezes acaba perdendo seu esplendor quando vivenciado por mulheres privadas de liberdade. $\mathrm{O}$ desvirtuamento da pureza e do fascínio que deveriam estar atrelados ao nascimento de uma nova vida é atestado em razão do tratamento desumano e degradante que usualmente é fornecido pelos agentes do SOE e pela equipe médico-hospitalar às mulheres presas grávidas. Trata-se da reprodução da lógica anteriormente anunciada, que associa os internos de nossas penitenciárias à inimigos, que teriam humanidade reduzida e que não seriam merecedores dos cuidados e delicadezas que todas as mães necessitam no instante de dar à luz.

Nestes termos, experiências de maus tratos e de impotência substituem a ansiedade e a alegria próprias da hora do parto. Carmem Mattos, Sandra Almeida e Paula Castro, ao debruçarem-se sobre a realidade prisional do Rio de Janeiro, identificaram o horror comumente vivenciado pelas presas gestantes neste evento. De acordo com as autoras:

\footnotetext{
Uma das situações recorrentes nos relatos das jovens e mulheres é quando do parto. Relatam que viveram 'momentos de terror' uma 'realidade à parte' durante a ida ao hospital para o parto e durante o nascimento de seus filhos. São submetidas, por parte das autoridades hospitalares, dos motoristas dos veículos de transporte das presas e dos agentes que as acompanham à condições, consideradas por elas, 'desumanas'. 60
}

Relatos fornecidos às educadoras Almeida, Mattos e Araújo, que entrevistaram vinte internas da Unidade Materno Infantil, demonstram com clareza o cenário acima apresentado. Joelma, mãe de dois filhos, vivenciou duas vezes a experiência do parto enquanto cumpria pena, tendo perdido um bebê em razão da falta de diligência médica. De acordo com a interna,

\footnotetext{
${ }^{60}$ MATTOS, Carmen Guimarães de; MACIEL, Sandra e CASTRO, Paula Almeida de. Educação e vulnerabilidade: um estudo etnográfico com jovens e mulheres em privação de liberdade. Revista Eletrônica de Educação, v. 7, n. 1, maio de 2013. Disponível em: http://www.reveduc.ufscar.br/index.php/reveduc/article/viewFile/615/231. Acesso em: 04/11/14, p. 42.
} 
seu parto deveria ter sido realizado por meio de uma cirurgia cesariana, o que não foi de pronto atendido pela equipe médica.

Na hora do parto tudo deu errado. (...) Eles tavam tentando normal, né, quando eles viram que eu não ia conseguir, já era tarde, a criança já tava vinte minutos sem respirar dentro da minha barriga (...) aplicaram anestesia em mim, a primeira não pegou, aplicaram a segunda, quebrou a agulha; ai na terceira pegou. Ai a criança teve uma parada cardíaca; ai por consequência ele deu oito paradas cardiacas e depois entrou em coma (...) ele ficou quatro meses internado, ai a ultima parada cardíaca ele não resistiu. ${ }^{61}$

Joelma ressalta, ainda, ter sido discriminada no hospital em razão de sua condição de gestante presa. Nas suas palavras: "pra senhora ter noção, eu sentindo dor, eu fui me apoiar no médico, no braço dele, ele virou pra mim e falou assim: 'Tira a mão de mim presa!'. Entendeu? Então aquilo ali foi horrivel pra mim. Foi horrivel! Sentindo aquela dor toda... „62.

Outro depoimento, fornecido por Edna, mãe de sete filhos, demonstra a negligência dos servidores que atuam no SOE. Estes, considerando-a como objeto e desprezando suas demandas, mostraram-se incapazes de encaminhá-la com prontidão à unidade hospitalar e fizeram com que a gestante desse à luz ao seu filho no interior da viatura de transporte, algemada e sem qualquer amparo médico.

\begin{abstract}
Quando foi no sábado, eu já amanheci passando mal legal, dia cinco. Aí as meninas lá pediu p chamar o SOE, que faz o transporte da gente aqui, de preso, pra poder me levar. Ai demorou muito! Ai quando eu sai pra poder ir, a mulher me algemou; eu passando muito mal, que eu já tava gelada... Ela me algemou; me botou atrás, não me levou na frente. (...) Invés de me levar direto, não, me levou num outro presídio por aqui (...) pra pegar um preso que tava passando mal... (...) Ai ficava um tempão lá dentro do presídio conversando... Que eu escutava eles conversando do lado de fora. Ai, quando ele entrou num outro presídio, eu comecei a bater na porta. Bater, bater, bater, porque a neném tava coroando. Ai eu algemada, coloquei a algema pra frente, tirei a bermuda, e comecei a bater: "Moço, abre aqui, moço"! Ai ele abriu e eu falei: "Moço, minha filha tá coroando, pelo amor de Deus, me tira daqui, tô com falta de ar"! Aí ele pegou e falou assim: "Não"! Bateu e me deixou trancada lá dentro. Eu
\end{abstract}

\footnotetext{
${ }^{61}$ Fragmento da entrevista de Joelma, realizada em agosto de 2010. In: ALMEIDA, Sandra, MATTOS, Carmem e ARAUJO, Adriane. Filhos e filhas de mulheres presas e vulnerabilidade socioeducacional. VIII Encontro Nacional da ANDHEP, 2014, p. 6. Disponível em: http://andhep.org.br/anais/arquivos/VIIIencontro/GT13.pdf. Acesso em: 01/11/14, p. 9.

${ }^{62}$ Ibid., p. 6.
} 
tive ela trancada... ${ }^{63}$

Ressalta-se que Edna teve seu filho dentro do veículo do SOE, trancada e algemada. O uso de algema nesta circunstância, vale frisar, representa em si abuso do direito e violação à dignidade da presa, uma vez que sua utilização demonstra-se absolutamente desnecessária, tendo em vista que a presa gestante, quando em trabalho de parto, não representa qualquer ameaça à segurança local. A imposição de algema, neste sentido, apenas importa na desqualificação da grávida enquanto sujeito de direitos.

Outro depoimento, fornecido por Silmara, reitera a indolência dos servidores do SOE. A gestante foi encaminhada à maternidade juntamente com interna que possuía tuberculose, o que ameaça tanto a sua saúde, como a de seu bebê. De acordo com o relato da detenta, "Ela falou pra mim: 'Filha! Eu tô com tuberculose...' eu falei: ‘(..) fazer o que?' Eu num tenho, eu num tenho nojo, entendeu? Eu falei pra ela: 'Só que... né... é um risco que eu vou correr. Vou confiar em Deus. Vamo embora'. Ai ela: 'Ah, vou tentar não tossir muito'. Falei: 'Ai, tosse, pode tossir',"64.

Os depoimentos acima elencados demonstram apenas pequeno fragmento do universo de abusos e maus tratos perpetrados pelos agentes públicos contra as mulheres encarceradas no momento do parto. Nesta circunstância, as presas gestantes estão em estado de vulnerabilidade agravada, o que demanda, no lugar da frigidez e da discriminação verificadas, amparo estatal redobrado.

Após os momentos de horror muitas vezes atrelados ao parto, as mulheres são encaminhadas para a Unidade Materno Infantil, onde permanecem com seus filhos no período de lactação. Durante esta estadia na Unidade, espera-se que as detentas sejam mães em tempo integral. A vigilância, a disciplina e o controle encontram-se, nestes termos, revestidos pelo discurso da maternidade, uma vez que a mulher apenas pode

\footnotetext{
${ }^{63}$ Fragmento da entrevista de Edna, realizada em setembro de 2010. In: ALMEIDA, Sandra, MATTOS, Carmem e ARAUJO, Adriane. Op. cit., p. 7.

${ }^{64}$ Fragmento da entrevista de Silmara, realizada em agosto de 2010. In: ALMEIDA, Sandra, MATTOS, Carmem e ARAUJO, Adriane. Op. cit., p. 8.
} 
permanecer na companhia de seu filho se mostrar ser uma mãe dedicada.

Assim, a expectativa institucional acerca do papel das mães, nos termos firmados pelas psicólogas Cristina Addad e Maricy Santos, pressupõe que estas “estejam voltadas para a criança durante todo o dia, atendendo de pronto às suas necessidades, sob um olhar vigilante e crítico ${ }^{65}$. O exercício da maternidade no cárcere, neste sentido, exige exclusividade, sendo vedado à presa mãe o empenho de função que desvirtue a demanda por atenção integral à prole. Essa expectativa, ao distinguir os papéis de mãe e de presa, acaba por firmar uma incompatibilidade entre os institutos, já que para adequarem-se à figura materna as internas acabam sendo obrigadas a abrirem mão de determinadas garantias asseguradas aos presos em geral.

Neste panorama, atividades que não estão atreladas à limpeza do ambiente e ao cuidado dos bebês não podem, em hipótese alguma, ser exercidas pelas mães atenciosas. Deste modo, a atuação laboral carcerária e a atividade educacional - ações que de acordo com a LEP são fatores de remição de pena ${ }^{66}$ - estão vedadas às internas da UMI. A anunciada antinomia, ao colocar em choque direitos relacionados à maternidade e direitos das pessoas privadas de liberdade, faz com que algumas mulheres, priorizando sua rápida saída do presídio, optem por não permanecerem com seus filhos no cárcere, abrindo mão da influência nos primeiros meses de vida de seus bebês. Ainda de acordo com Addad e Santos:

\footnotetext{
Observamos que é sob a perspectiva do enaltecimento da maternidade, da dedicação integral aos filhos, do cuidado com o espaço onde coabitam com eles, é que as mães são valorizadas e identificadas como cuidadosas e dedicadas. Todavia, o direito a esta maternidade presencial é limitado e incompatível com benefícios como trabalho, que reduz o tempo da pena, ou visitas à família. Esta circunstância, não raro, é responsável pela decisão em prol de uma saída antecipada do bebê da UMI. As mulheres vêem-se então submetidas a transitar
}

\footnotetext{
${ }^{65}$ ADADD, Cristina; SANTOS, Maricy e NASCIMENTO, Tuane. Op. cit., p. 4.

${ }^{66}$ BRASIL. Lei de Execução Penal. Op. cit., art. 126: "O condenado que cumpre a pena em regime fechado ou semiaberto poderá remir, por trabalho ou por estudo, parte do tempo de execução da pena. $\S 1^{\circ}$ A contagem de tempo referida no caput será feita à razão de: I - 1 (um) dia de pena a cada 12 (doze) horas de frequência escolar - atividade de ensino fundamental, médio, inclusive profissionalizante, ou superior, ou ainda de requalificação profissional - divididas, no mínimo, em 3 (três) dias; II - 1 (um) dia de pena a cada 3 (três) dias de trabalho".
} 
por situações e escolhas que denunciam a incompatibilidade entre os direitos de presa e os direitos de mãe. ${ }^{67}$

Atesta-se, nestes termos, que o dilema existente entre o exercício da maternidade e a diminuição do tempo de pena faz com que as mulheres encarceradas sejam obrigadas a enfrentar um duro processo decisório, que envolve, invariavelmente, a perda de um direito em razão da sobreposição de outro, em um contexto em que os direitos de mãe e de presa não são adequadamente equacionados. Compreende-se, com isto, que a submissão das mulheres a esta decisão pressupõe uma interferência estatal indevida na vida privada e na autonomia reprodutiva das detentas e gera, nos termos firmados por Aline Gomes e Anna Paula Uziel, uma ambivalência acerca da assunção ou não do papel de mãe. Nas palavras das autoras:

O confinamento e a condição de dar à luz a um filho que permanecerá "preso" durante seus primeiros meses de vida provocam reações ambivalentes quanto a aceitar ou rejeitar a maternidade. Expressam, justamente, o antagonismo entre o ambiente de privação de liberdade, que nega radicalmente qualquer manifestação subjetiva, e o processo de geração de uma nova vida. ${ }^{68}$

Integra a decisão acerca da permanência das crianças no cárcere a análise da rotina institucional da UMI, rotina esta que, de acordo com Cristina Addad e Maricy Santos, caracteriza-se pelo ócio quase total ${ }^{69}$. As autoras, ao analisarem relatos das internas da Unidade, indicam que:

Falam-nos sobre uma experiência subjetiva de imobilismo, retratado na circularidade da vivência temporal: nada muda, todo dia é igual, a rotina se repete. Surgem relatos como 'aqui você está exclusivamente para a criança'; 'acorda, dá banho no bebê, depois toma banho e fico cuidando o dia todo dela'; 'acordava cinco horas da manhã, tinha a minha faxina, dava de mamar, tomava banho, botava meu filho para dormir, brincava com ele... todos os dias era a mesma coisa'. ${ }^{70}$

\footnotetext{
${ }^{67}$ ADADD, Cristina; SANTOS, Maricy e NASCIMENTO, Tuane. Op. cit., p. 5.

${ }^{68}$ GOMES, Aline, UZIEL, Anna Paula, SANTOS, Maricy e outras. Reflexóes sobre a maternidade no sistema prisional: o que dizem técnicas e pesquisadoras. Convênio de Cooperação Técnica entre a UERJ e a SEAP/RJ Disponível em:http://www.abrapso.org.br/siteprincipal/images/Anais_XVENABRAPSO/366.\%20reflex\%D5e s\%20sobre\%20a\%20maternidade $\% 20$ no\%20sistema\%20prisional.pdf. Acesso em: 04/11/14, p. 6 .

${ }^{69}$ ADADD, Cristina; SANTOS, Maricy e NASCIMENTO, Tuane. Op. cit., p. 6.

${ }^{70}$ Ibid., p. 6.
} 
Evidencia-se, deste modo, a passividade que rege o local e a pobreza de estímulos e de descobertas atestadas na Unidade. As crianças que ali residem vivenciam experiências limitadas, longe de animais, brincadeiras e elementos lúdicos que estimulem suas potencialidades. Seguem o rito institucional que, conforme apontado, se repete, não concedendo espaço para criações e espontaneidades próprias do mundo extramuros. Assim, ainda nos termos de Addad e de Santos, "podemos pensar o quanto esta possibilidade limitada de experiências cotidianas deve contrastar-se com a vida em liberdade, alinhavada por uma sucessão de vivências diferenciadas, e que esta percepção se constrói comparativamente a outras situações vividas e registradas na memória,"71.

A apuração da rotina da UMI pressupõe o enfrentamento do momento da separação entre mães e bebês, possivelmente um dos mais delicados e traumáticos tanto para as genitoras, quanto para seus filhos. Nos seis meses de permanência na Unidade, uma equipe técnica formada por uma psicóloga e uma assistente social acompanha as relações de mães e bebês, elaborando relatórios de avaliação, que serão encaminhados para a II Vara da Infância, Juventude e Idoso de Santa Cruz, órgão responsável por decidir o destino das crianças que nascem no Complexo Gericinó ${ }^{72}$.

A partir da manifestação da equipe técnica da UMI, o judiciário deve pronunciar-se, determinando se a criança a) ficará sob os cuidados de um guardião, b) de uma família substituta ou se c) será abrigada em uma instituição. A opção pelo guardião, mais recomendada, depende do comparecimento periódico do candidato ao cargo à Unidade, no período de permanência da criança, para responder às entrevistas da equipe técnica. Em geral, é eleito como guardião pessoa da família da detenta, ou de sua família estendida, também denominada família em rede, o que inclui pessoa amiga, próxima do seio familiar. Não sendo verificado sujeito apto a

\footnotetext{
${ }^{71}$ Ibid., p. 6.

${ }^{72}$ UZIEL, Anna Paula (org.). Maternidade e Sistema Penitenciário. Convênio de Cooperação Técnica SEAP-UERJ. Edital CNPq: 57/2008; Processo: 402728/2008-4, p. 39/40.
} 
assumir a função de guardião, tem-se optado pela inserção da criança em família substituta, a fim de evitar o acolhimento institucional ${ }^{73}$.

As educadoras Almeida, Mattos e Araujo chamam atenção à angústia usualmente relatada pelas internas da Unidade em relação ao momento da separação, sentimento provocado pela "ansiedade diante da incerteza em relação ao destino de seus filhos" ${ }^{\text {"74 }}$. A indeterminação própria da separação, vale frisar, provoca consequências ainda mais sérias quando a interna não tem qualquer familiar para responsabilizar-se por seu filho, o que alimenta o medo de uma institucionalização indesejada.

Uma vez questionadas acerca do prazo de permanência de seis meses, as internas dividem opiniões, havendo aquelas que afirmam ser muito pequeno o tempo de permanência, e outras que entendem que as crianças não poderiam ficar no cárcere por mais tempo. Neste sentido, Daffyny, de 21 anos, afirma que: "a gente fica mal com o prazo de seis meses, mas tem que pensar na criança, ver o lado dela. Não é legal criança ficar dento da cadeia,"75. Bárbara, de 37 anos, na mesma esteira, ressalta que: "seria maravilhoso ficar com ela a minha pena toda, mas a gente é muito egoísta. Imagina ficar um ano só vendo a mim... uma criança que não vê um cachorro, uma pracinha. Seria melhor se ficasse só quatro meses porque eles sofreriam menos. Tem gente que nem queria que o filho estivesse aqui, a família obriga",76.

De forma distinta, também encontra-se relatos que defendem a permanência por um ano. Neste sentido, uma interna afirma que: "acho que deveria ficar um ano, seis meses é muito pouco. É muito difícil ter que pensar em me separar dela, porque todos os dias vejo minha filha, não sei quanto tempo vou ficar na cadeia"77. Outro depoimento versa que: "poderia ser um ano, é mais tempo para se acostumar com a mãe",78.

\footnotetext{
${ }^{73}$ Ibid., p. 39/40.

${ }^{74}$ ALMEIDA, Sandra, MATTOS, Carmem e ARAUJO, Adriane. Op. cit., p. 11.

${ }^{75}$ GOMES, Aline. Op. cit., p. 68.

${ }^{76}$ Ibid., p. 68.

${ }_{77}^{71}$ ADADD, Cristina; SANTOS, Maricy e NASCIMENTO, Tuane. Op. cit., p. 6/7.

${ }^{78}$ Ibid., p. 6/7.
} 
A partir do panorama geral apresentado, compreende-se que o exercício da maternidade vivenciado pelas mulheres privadas de liberdade na Unidade Materno Infantil distancia-se da maternidade verificada em liberdade, fora dos limites, normas, procedimentos e angústias atestadas no cárcere. Aline Figueiredo Gomes e Anna Paula Uziel ressaltam as particularidades experimentadas pelas mães encarceradas, indicando que:

\begin{abstract}
A angústia foi um tema gerador de interpretações acerca do comportamento das detentas em torno da experiência da maternidade. Ressaltaram-se também outras questões trazidas pelas mulheres nos atendimentos, como a diferenciação do ambiente prisional para o ambiente fora prisão; a escassez de visitas; a falta de apoio do companheiro; incertezas sobre com quem os filhos ficarão; o rompimento dos laços; a impossibilidade de maternagem na situação de privação de liberdade e que especificidades isso provoca, como por exemplo, o desejo manifesto de "dar o filho para adoção", entre outras. Logo, o contexto prisional afirma-se como um universo diferente na medida em que provoca uma fragilização dos vínculos familiares e afetivos com aqueles que estão fora deste ambiente. ${ }^{79}$
\end{abstract}

Ser mãe dentro da prisão, conforme evidenciado, pressupõe desafios, superações e adaptações que nem sempre se compatibilizam com os direitos das crianças e das pessoas privadas de liberdade. Após a identificação dos principais pontos que circundam a maternidade na UMI, serão analisados os standards jurídicos de proteção da criança, no intuito de contrastá-los com a experiência do aprisionamento por tabela.

\footnotetext{
${ }^{79}$ GOMES, Aline, UZIEL, Anna Paula, SANTOS, Maricy e outras. Op. cit., p. 5.
} 


\section{Terceiro Capítulo: Viabilidade jurídica da permanência de crianças no cárcere}

\subsection{Normativa de proteção da criança e prospectivas do Direito Internacional dos Direitos Humanos:}

As crianças, ao longo das últimas décadas, assistiram à consolidação de seus direitos no cenário jurídico interno e internacional. A Convenção sobre os Direitos da Criança, adotada em 1989, e o Estatuto da Criança e do Adolescente, promulgado em 1990, são erguidos como instrumentos essenciais à afirmação de novo paradigma, que deixa de enxergar as crianças como mero objeto, passando a firmar seus direitos e sua condição de ser em desenvolvimento, merecedor de uma especial proteção. A Comissão Interamericana de Direitos Humanos, neste sentido, ratificou no relatório Direito da Criança à Família a visão da criança enquanto "sujeito titular de direitos, que devem ser respeitados e promovidos em sua integralidade, deixando-se assim para trás a concepção de criança entendida como um mero objeto destinatário de assistência e proteção" ${ }^{80}$.

Consagra-se, nos termos anunciados, o direito das crianças a medidas especiais de proteção, que devem ser garantidas pela família, pela sociedade e pelo Estado ${ }^{81}$, passando este a ocupar uma posição de garante frente às crianças de sua jurisdição, o que o obriga a adotar medidas específicas para atender à diferenciada proteção infantil ${ }^{82}$. A CIDH versa sobre os fundamentos deste cuidado especial, indicando que:

O dever de proteção especial se fundamenta no reconhecimento das condições especiais que as crianças possuem em razão do desenvolvimento progressivo de

\footnotetext{
${ }^{80}$ OEA. Comissão Interamericana de Direitos Humanos. Direito da Criança à Família. Cuidado Alternativo. Ponto fim à Institucionalização nas Américas. Aprovado em 17 de outubro de 2013, p. 15. Disponível em: http://www.oas.org/es/cidh/infancia/docs/pdf/Informe-derecho-nino-afamilia.pdf. Acesso em: 01/11/14. Todas as decisões da CIDH serão traduzidas do espanhol.

${ }^{81}$ OEA. Convenção Americana sobre Direitos Humanos. Assinada em 22 de novembro de 1969, art. 19; Declaração Americana dos Direitos e Deveres do Homem. Aprovada em 1948, art. VII; Protocolo de direitos Econômicos Sociais e Culturais. Protocolo adicional à CADH, art. 16.

${ }^{82}$ OEA. Direito da Criança à Família. Op. cit., p. 13/14.
} 
todas as suas facetas - em níveis físicos, cognitivos, emocionais, psicológicos e sociais -, o que as leva a depender dos adultos para o efetivo acesso e desfrute de todos os seus direitos, assim como para o exercício das ações judiciais destinadas a exigir os mesmos. ${ }^{83}$

Nossa Constituição Federal, em seu artigo 227, reproduz a prioridade absoluta que deve ser concedida às crianças pela família, sociedade e Estado, no intuito de que os direitos fundamentais dos infantes venham a ser efetivados. O ECA, na mesma esteira, anuncia a proteção integral e prioritária às crianças e adolescentes como um de seus princípios norteadores ${ }^{84}$ e a Convenção sobre os Direitos da Criança ressalta, em seu preâmbulo, a preocupação do direito internacional dos direitos humanos com a garantia de uma proteção diferenciada para as crianças ${ }^{85}$.

A aludida proteção especial infantil também deve ser estendida às mulheres nos períodos de gestação e amamentação. Esta é a disposição dos artigos VII da Declaração Americana dos Direitos e Deveres do Homem e 10.2 do Pacto Internacional sobre Direitos Econômicos, Sociais e Culturais, que afirmam, respectivamente, que "toda mulher em estado de gravidez ou em época de lactação, assim como toda criança, têm direito à proteção, cuidados e auxílios especiais" e que "deve-se conceder proteção especial às mães por um período de tempo razoável antes e depois do parto”.

Imperioso ressaltar que a proteção fornecida para as mulheres necessita, nos termos firmados pela Convenção sobre a Eliminação de todas as formas de Discriminação contra a Mulher, especialmente no artigo 12.2, estar livre de qualquer modalidade de discriminação. Neste teor, tanto

\footnotetext{
${ }^{83}$ OEA. Direito da Criança à Família. Op. cit., p. 13/14.

${ }^{84}$ BRASIL. Lei $n$. 8069 de 13 de julho de 1990. Dispõe sobre o Estatuto da Criança e do Adolescente e dá outras providências, art. 100, parágrafo único, II.

${ }^{85}$ ONU. Convenção sobre os Direitos das Crianças. Adotada pela Assembleia Geral das Nações Unidas em 20 de novembro de 1989. Preâmbulo: "Tendo presente que a necessidade de garantir uma protecção especial à criança foi enunciada pela Declaração de Genebra de 1924 sobre os Direitos da Criança (5) e pela Declaração dos Direitos da Criança adoptada pelas Nações Unidas em 1959 (2), e foi reconhecida pela Declaração Universal dos Direitos do Homem, pelo Pacto Internacional sobre os Direitos Civis e Políticos (nomeadamente nos artigos 23 e 24) 4, pelo Pacto Internacional sobre os Direitos Económicos, Sociais e Culturais (nomeadamente o artigo 10) e pelos estatutos e instrumentos pertinentes das agências especializadas e organizações internacionais que se dedicam ao bem-estar da criança".
} 
mulheres em liberdade quanto mulheres que se encontrem cumprindo pena em nossos presídios são merecedoras de cuidados especiais nos momentos atrelados à maternidade, notadamente a gestação e a amamentação.

Atendendo a esta especificidade, nossa Constituição Federal ressaltou, no rol dos direitos fundamentais - art. 5, inciso L -, o direito das presidiárias a permanecerem com seus filhos no período de amamentação e o ECA determinou, em seu artigo 9, o dever do poder público de propiciar as "condições adequadas para o aleitamento materno, inclusive aos filhos de mães submetidas a medida privativa de liberdade".

A efetivação dos direitos das mulheres e dos direitos de seus filhos deve, invariavelmente, caminhar de forma conjunta. Não se pode abrir mão da plenitude de um, a fim de atender à garantia de outro, já que ambos são merecedores de especial tutela jurídica. Deste modo, no intuito de analisar se o exercício do direito à lactação no cárcere preserva os direitos das crianças, é preciso debruçar-se sobre os postulados que norteiam a especial proteção infantil, quais sejam: a) o direito à família, b) o direito ao desenvolvimento integral e c) o princípio do interesse superior da criança.

$\mathrm{O}$ direito à família, amplamente consagrado no plano interno e internacional $^{86}$, é considerado um direito fundamental, intimamente ligado ao desenvolvimento psicossocial infantil. A Convenção sobre os Direitos da Criança reconhece, nos termos acima destacados, que a "criança, para o desenvolvimento harmonioso da sua personalidade, deve crescer num ambiente familiar, em clima de felicidade, amor e compreensão" ${ }^{\$ 7}$.

Trata-se de direito primário que, segundo a Comissão Interamericana de Direitos Humanos, "encontra-se intimamente relacionado com a efetiva vigência de todos os direitos da criança em função do lugar que a família

\footnotetext{
${ }^{86}$ BRASIL. Constituição da República. Op. cit., artigos 226 e 229; BRASIL. Lei n. 8069. Op. cit., artigos 19; ONU. Convenção sobre os Direitos das Crianças, Op. cit., artigos 5, 7, 5, 7, 8 e 9.

${ }^{87}$ ONU. Convenção sobre os Direitos das Crianças. Op. cit., preâmbulo.
} 
ocupa na vida da criança e em seu rol de proteção e carinho" ${ }^{\text {,8 }}$. Neste sentido, a família é eleita como núcleo central de proteção infantil ${ }^{89}$.

Compõe o âmago do direito à família o direito da criança de crescer e se desenvolver no seio familiar e o direito de ser criada por seus pais. Este se encontra elencado no art. 7.1 da Convenção temática das Nações Unidas, que determina o direito da criança de "conhecer seus pais e ser cuidada por eles". Ao lado deste direito, encontra-se o dever do Estado de apoiar a família para que esta possa desempenhar integralmente suas funções ${ }^{90}$. A Corte Interamericana de Direitos Humanos, neste panorama, afirma que “em principio, a família deve proporcionar a melhor proteção para as crianças (...). E o Estado tem a obrigação não apenas de dispor e executar diretamente medidas de proteção às crianças, mas também favorecer, de maneira ampla, o desenvolvimento e o fortalecimento do núcleo familiar"91.

Muito embora existam situações sociais e jurídicas capazes de abalar a garantia plena do direito da criança à família, a Convenção sobre os Direitos da Criança consagra que pais e filhos apenas podem ser afastados se esta medida for recomendada em nome do melhor interesse infantil ${ }^{92}$. Neste contexto, a separação verificada em razão da condenação criminal de um dos genitores deve ter sua validade apurada em função dos direitos da criança. A Comissão sobre Temáticas de Gênero da Defensoria Geral da Nação Argentina, nesta linha interpretativa, afirma que:

Embora a Convenção sobre os Direitos da Criança estabeleça que as crianças podem ser separadas de seus pais como resultado do encarceramento de algum deles (art. 9.4), esta hipótese deve ser interpretada em conjunto com as demais regras, em especial com a que fixa que esta separação unicamente deve ocorrer quando for aconselhável pelo interesse superior da criança (art. 9.1)..$^{3}$

\footnotetext{
${ }^{88}$ OEA. Direito da Criança à Família. Op. cit., p. 21.

${ }^{89}$ Ibid., p. 17.

${ }^{90}$ OEA. Direito da Criança à Família. Op. cit., p. 18.

${ }^{91}$ OEA. Corte IDH. Condición Jurídica y Derechos Humanos del Niño. Opinião Consultiva OC17/02 de 28 de agosto de 2002. Serie A No. 17, parágrafo 66. Todas as decisões da Corte IDH serão traduzidas do espanhol.

92 ONU. Convenção sobre os Direitos das Crianças. Op. cit., art. 9.

${ }^{93}$ GIORDANO, Alberto. Ministério Público da Defesa da Argentina. Defensoria Geral da Nação. Comissão sobre Temáticas de Gênero. Disponível em:

http://www.mpd.gov.ar/articulo/downloadAttachment/id/2179. Acesso em: 04/11/14, p. 5. Tradução livre do espanhol.
} 
Evidencia-se, nestes termos, uma vinculação entre os direitos da criança e a atuação do Estado. Tendo o dever de zelar pela atenção prioritária infantil, efetivando medidas legislativas e programas governamentais que amparem plenamente as crianças, o Estado está proibido de levar a cabo qualquer ação que importe em uma relativização dos direitos infantis, ainda que esta esteja atrelada ao exercício regular de sua pretensão punitiva penal. Neste enredo, ressalta-se pronunciamento da Corte IDH, que indica que "a criança deve permanecer em seu núcleo familiar, a menos que existam razões determinantes, em função de seu interesse superior, que determinem sua separação da família” ${ }^{, 4}$.

Deste modo, compreende-se que os direitos da criança à família e aos cuidados paternos apenas podem ser flexibilizados se a separação entre pais e filhos, operada em razão de condenação criminal, mostrar-se favorável à garantia dos demais direitos infantis, como o direito ao desenvolvimento integral e ao princípio de seu interesse superior.

O direito ao desenvolvimento integral, consagrado no art. 27 da Convenção sobre os Direitos da Criança, engloba todos os aspectos da vida do infante, dentre eles o físico, o mental, o espiritual, o moral e o social. Trata-se de direito que possui uma concepção holística, atrelado ao desenvolvimento multifacetado das crianças, que demanda cuidados e concepções relacionados a cada uma das parcelas do psiquismo infantil.

Sua análise é de extrema importância no enfrentamento dos reflexos que o cárcere é capaz de provocar nas crianças de tenra idade que nele residem. Se não se pode admitir, em nome do direito à família, uma separação que não atenda ao melhor interesse da criança, também não se pode deixar de aferir as consequências multipolarizadas que as experiências vivenciadas nos primeiros momentos de vida nos presídios são capazes de provocar em todos os aspectos do desenvolvimento infantil.

\footnotetext{
${ }^{94}$ OEA. Corte IDH. Opinião Consultiva OC-17/02. Op. cit., parágrafo 77.
} 
Assim, deve-se analisar os direitos à família e ao desenvolvimento integral tendo em vista o principal postulado do sistema de proteção infantil, que deve irradiar a interpretação de todas as suas normas: o princípio do interesse superior da criança. Este, consagrado no ECA e na Convenção sobre os Direitos da Criança ${ }^{95}$, pressupõe a priorização do interesse infantil sobre todos os demais interesses e direitos em pauta. Nos termos firmados pela Corte IDH, o referido princípio encontra-se intimamente relacionado com a efetivação plena dos direitos dos infantes, o que o leva a nortear a formulação e a aplicação de todas as normas que produzam efeitos sobre a vida das crianças. Nas palavras da Corte:

\begin{abstract}
A Convenção sobre os Direitos da Criança alude ao interesse superior da criança (arts. 3, 9, 18, 20, 21, 37 e 40) como ponto de referência para assegurar a efetiva realização de todos os direitos contemplados no instrumento, cuja observância permitirá ao sujeito o mais amplo desenvolvimento de suas potencialidades. A este critério devem aderir as ações do Estado e da sociedade no que diz respeito à proteção das crianças e à promoção e preservação de seus direitos. ${ }^{96}$
\end{abstract}

Nestes termos, ressalta-se pronunciamento do Comitê dos Direitos da Criança, que ratifica a importância central do interesse superior da criança na atuação estatal. Indica o Comitê que "todos os órgãos ou instituições legislativas, administrativas e judiciais devem aplicar o princípio do interesse superior da criança considerando, de forma sistêmica, como os direitos e os interesses da criança se veem afetados ou se verão afetados pelas decisões e medidas adotadas" ${ }^{\prime 97}$.

A observância dos reflexos da privação de liberdade nos filhos das apenadas, deste modo, pressupõe um estudo pormenorizado de todos os direitos infantis afetados e a primazia do interesse superior da criança. $\mathrm{O}$ Comitê dos Direitos da Criança, ao apreciar a temática, ponderou que "quando a acusada tenha a responsabilidade de cuidar de um filho, o

\footnotetext{
${ }^{95}$ BRASIL. Lei $n .8069$. Op. cit., art. 100, parágrafo único, IV; ONU. Convenção sobre os Direitos das Crianças, Op. cit., artigo 3.1.

${ }^{96}$ OEA. Corte IDH. Opinião Consultiva OC-17/02. Op. cit., parágrafo 62.

${ }^{97}$ ONU. Comitê dos Direitos das Crianças. Observação Geral n. 5. Medidas generales de aplicación de la Convención sobre los Derechos del Niño, adotada em outubro de 2003, par. 12. Todos os pronunciamentos do Comitê dos Direitos das Crianças serão traduzidos do espanhol.
} 
Comitê recomenda que profissionais competentes considerem cuidadosa e independentemente o princípio do interesse superior da criança (art. 3) e que este seja levado em conta em todas as decisões relacionadas com a detenção, em particular com a detenção provisória e com a condenação"98.

Ainda acerca do aprisionamento materno e do encarceramento infantil por tabela, o Comitê recomenda que "o Estado Parte examine a atual prática que prevê que as crianças vivam com seus pais no cárcere, no intuito de que esta estadia se limite aos casos em que o interesse superior da criança seja atendido, e que vele para que as condições de vida sejam propicias ao desenvolvimento harmonioso de sua personalidade" ${ }^{99}$. No mesmo sentido dispõe as Regras de Bangkok, adotadas pela Assembleia Geral da ONU, que indicam que "toda decisão que permitir que as crianças permaneçam com suas mães no cárcere deverão se basear no interesse superior da criança. As crianças que se encontrem no cárcere com suas mães não serão tratadas como reclusos"100.

Conclui-se, nos termos firmados pelo Comitê das Nações Unidas, que mulheres aprisionadas apenas podem permanecer com seus filhos no cárcere se esta prática atender ao interesse superior das crianças encarceradas, ou seja, se for comprovado que esta é a medida mais adequada para garantir os direitos infantis. A fim de apurar a compatibilidade entre este princípio norteador dos direitos da criança e o meio carcerário, entende-se ser necessário levar em consideração o

\footnotetext{
${ }^{98}$ ONU. Comitê dos Direitos das Crianças. Examen de los Informes Enviados por los Estados Partes en virtud del artículo 44 de la Convención sobre los Derechos del Niño. Observaciones finales: Tailandia, Informe $\mathrm{CRC} / \mathrm{C} / \mathrm{THA} / \mathrm{CO} / 2$, parágrafo 48.

${ }^{99}$ ONU. Comité de los Derechos del Niño. Examen de los Informes Enviados por los Estados Partes en virtud del artículo 44 de la Convención sobre los Derechos del Niño, Observaciones finales: Nepal, CRC/C/15/Add.261, 21/09/2005, parágrafo 52.

${ }^{100}$ ONU. Regras de Bangkok. Adotada pela Assembleia Geral em 16/03/11. Resolução A/RES/65/229, Regra 49.4 Disponível https://www.unodc.org/documents/commissions/CCPCJ/Crime_Resolutions/20102019/2010/General_Assembly/A-RES-65-229.pdf. Acesso em: 03/11/14. Ver também Resolução do Parlamento Europeu, adotada em 2008 que "recomenda que a detenção das mulheres grávidas e das mães que tenham consigo um ou mais filhos menores de idade não seja mais que um recurso de última instância e que, neste caso extremo, estas possam dispor de uma cela mais espaçosa, se possível individual, e recebam atenção especial, em particular em matéria de alimentação e higiene (...)”. In: SIMONE, Vanessa Fusco Nogueira. Op. cit., p. 89. Tradução livre do inglês.
} 
panorama geral de violação de direitos humanos que rege nossos presídios, atentando-se, especialmente, ao estado de vulnerabilidade que, per se, é vivenciado pelas pessoas privadas de liberdade. Acerca desta vulnerabilidade, a CIDH afirma que "o isolamento do mundo exterior produz em qualquer pessoa sofrimentos morais e perturbações psíquicas, a coloca em uma situação de particular vulnerabilidade"101.

Deste modo, tendo em vista a análise até então desenvolvida acerca da condição de vida atestada em nossos presídios e dos pormenores atrelados à maternidade vivenciada na Unidade Materno Infantil - universo da pesquisa -, se passará a demonstrar como o ambiente carcerário não se compatibiliza, em absolto, com o melhor interesse da criança.

\subsection{A incompatibilidade da norma penal brasileira com 0 princípio do interesse superior da criança:}

As crianças, merecedoras de cuidados diferenciados, de estímulos lúdicos e de uma especial proteção, quando fadadas a perderem seus primeiros meses ou anos de vida no interior dos muros de nosso sórdido sistema prisional tornam-se incapazes de desenvolver, de forma sadia, suas potencialidades. A rotina institucional, as normas, a obediência hierárquica, a frieza e a passividade que regem todos os presídios marcam a construção da personalidade dos pequenos infantes encarcerados por tabela.

Apesar das especificidades notadas na Unidade Materno Infantil, provavelmente uma das mais bem equipadas do país, esta é considerada inapta a atender as múltiplas necessidades atreladas ao pleno desenvolvimento das crianças. Luciano André Losekann, juiz auxiliar da presidência do $\mathrm{CNJ}$, neste panorama, afirma que seria utópico considerar que os presídios brasileiros seriam capazes de oferecer um espaço adequado

\footnotetext{
${ }^{101}$ OEA. Comissão Interamericana de Direitos Humanos. Justicia juvenil y derechos humanos en las Américas. Aprovado em 13 de julho de 2011, par. 262. Disponível em: http://www.oas.org/es/cidh/infancia/docs/pdf/JusticiaJuvenil.pdf. Acesso em: 01/11/14.
} 
às exigências infantis ${ }^{102}$, indicando ainda que "deixar meninos e meninas crescendo dentro de unidades prisionais, por melhor que elas sejam, é estigmatizá-los" $" 103$.

O presídio, mesmo que habitado por bebês ou crianças, não perde sua essência, isto é, não deixa de ser caracterizado como instituição total, que inibe a construção de novos horizontes, permitindo, tão somente, a reprodução de enraizada lógica pautada pela disciplina e pela segurança. Nestes termos, as crianças aprisionadas terminam por dividir com suas genitoras as angústias próprias da privação de liberdade. Rosângela Santa Rita, assistente social, assevera acerca do tema que "as crianças acabam, na prática, ficando presas também, com horários até para banho de sol e muitas vezes sem critérios que garantam o direito à liberdade, ao respeito e à dignidade como pessoa em processo de desenvolvimento, como determina o Estatuto da Criança e do Adolescente"104.

O escritório argentino da Unicef, na mesma direção, denuncia as intempéries da permanência de crianças nos presídios, chamando atenção ao elevado grau de vulnerabilidade que o cárcere firma sobre estas. Nos dizeres da instituição: "permanecer com suas mães no cárcere não parece ser a melhor opção. No âmbito carcerário, as meninas e meninos devem enfrentar as mesmas dificuldades que suas mães em relação à garantia de seus direitos em matéria de educação, saúde e vínculo com o exterior, porém com um maior grau de vulnerabilidade" $" 105$.

Imperioso, nesta perspectiva, analisar os reflexos que o meio carcerário é capaz de produzir nos filhos das apenadas. De acordo com a

\footnotetext{
${ }^{102}$ MARIZ, Renata. Dúvida sobre o período que um bebê pode ficar com a mãe na cadeia sem prejuízo à criança persiste. Correio Braziliense Online, publicado em 10 de agosto de 2010, p. 1. Disponível em: http://www.correiobraziliense.com.br/app/noticia/brasil/2010/08/10/interna_brasil,206879/index.s html. Acesso em: 01/11/14.

103 Ibid., p. 1.

104 RITA, Rosângela Santa. In: ROMERO, Thiago. Infância comprometida. FAPESP Online. Disponível em: http://agencia.fapesp.br/infancia_comprometida/6623/. Acesso em: 01/11/14.

${ }^{105}$ UNICEF. Escritório da Argentina. Mujeres presas: la situación de las mujeres embarazadas o con hijos/as menores de edad. Edição de out. de 2008, p. 4. Disponível em: http://www.unicef.org/argentina/spanish/Libro_Mujeres_Presas.pdf. Acesso em: 10/10/14. Tradução livre do espanhol.
} 
LEP, crianças menores de seis meses devem permanecer em berçários e crianças com até sete anos devem permanecer em creches no interior de nossos presídios. A apreciação da referida norma é capaz de causar espantos. Afinal, como admitir a privação da liberdade de uma criança até os seus sete anos de idade? Esta indagação, apesar de pertinente e necessária, deve igualmente verificar-se em relação à permanência atestada tão somente até os seis meses de vida dos bebês, uma vez que não pode-se deixar de considerar que as crianças, a partir do nascimento, são seres em desenvolvimento, altamente impactados pelo ambiente que os rodeia.

Laura Noemí Lora, professora e investigadora da Universidade de Buenos Aires, ressalta, nos termos acima anunciados, que quando encarceradas na companhia de suas mães, as crianças são obrigadas a conviverem com noções incompatíveis com o universo infantil. Neste sentido, a autora indica que as relações que envolvem a lei, a exclusão, o delito, os agentes carcerários, dentre outros, são capazes de causar um verdadeiro estigma na formação dos infantes aprisionados, chegando a representar um tratamento degradante, inumano e cruel. Em suas palavras:

Lembre-se de que a criança está em uma etapa inicial e central de seu desenvolvimento, que inevitavelmente deixará marcas indeléveis na configuração de seu psiquismo. A criança se vê obrigada a familiarizar-se com conceitos (lei, castigo, exclusão, delito, etc.) que não deveria estar obrigada a familiarizar-se. Se vê obrigada a familiarizar-se com um coletivo de pessoas (vinculadas à Justiça Criminal) que tão pouco deveria estar obrigada a familiarizar-se. Isto resulta humilhante para qualquer pessoa. Pense nas únicas imagens que a criança terá disponível (ou melhor, não terá) para identificar-se. O estigma que representa o encarceramento repercute ainda, de modo evidente e igualmente dramático, na reputação da criança em sua comunidade, onde cedo ou tarde deverá ser reinserida. Se, em poucas palavras, a reclusão é humilhante para um adulto, ela é simplesmente desumana, degradante e cruel para crianças com menos de cinco anos de idade. ${ }^{106}$

\footnotetext{
${ }^{106}$ LORA, Laura Noemí. Niños y madres que permanecen en establecimientos carcelarios: escenarios de conflito. XII Jornadas Nacionales de Filosofía y Ciencias Políticas. Universidad Nacional de Mar del Plata, Facultad de Derecho, 2012, p. 8. Disponível em: http://www.derecho.uba.ar/investigacion/investigadores/publicaciones/lora-ninos-y-madres-quepermanecen-en-establecimientos-carcelarios-escenarios-de-conflicto.pdf. Acesso em: 02/11/14. Tradução livre do espanhol.
} 
Analisando o tema a partir de uma abordagem Winnicottiana, compreende-se os reflexos do cárcere nos filhos das apenadas de uma forma ainda mais séria e decisiva, já que se identifica, nos termos firmados pelo pediatra e psicanalista inglês, a complexidade afetiva e perceptiva da vida emocional dos bebês ${ }^{107}$. Carlos Alberto Plastino, ao debruçar-se sobre o pensamento do autor, chama atenção à capacidade infantil de apreensão da realidade, o que desperta a inquietante possibilidade de os momentos vivenciados no cárcere pelas crianças repercutirem, incisivamente, em toda sua história de vida. Nos seus dizeres:

Muito antes de tornar-se capaz de se relacionar com o mundo através das construções significantes da cultura a que pertence, o bebê possui complexas formas de percepção, de apreensão, de registro de experiências - memória - e de pensamentos. Nesses processos iniciais são construídos e reconstruídos, através do incessante processo imaginário, os conteúdos de sentido fundamentais à constituição do psiquismo. ${ }^{108}$

Constata-se, deste modo, que o ambiente em que a criança está inserida influencia de forma determinante no processo de construção de sua subjetividade $^{109}$. Um ambiente suficientemente bom, com a presença cuidadora materna e com estímulos externos positivos, nestes termos, mostra-se crucial para a formação de uma base positiva, que permitirá o desabrochar dos potenciais infantis. Acerca da importância do ambiente na construção do psiquismo dos infantes, ressalta-se trecho de Carlos Plastino:

\begin{abstract}
(A)s reações do bebê ao comportamento ambiental, sua espontaneidade liberada por um ambiente confiável, ou, alternativamente, seu recuo defensivo numa atitude de adaptação a um ambiente intrusivo, exigem que se reconheça no bebê desde o início da vida - a capacidade de perceber seu ambiente e de tingir de sentido suas experiências com este. As emoções vivenciadas, sem possuir qualquer representação linguageira, são portadoras de sentidos fundamentais. ${ }^{110}$
\end{abstract}

\footnotetext{
${ }^{107}$ PLASTINO, Carlos Alberto. Vida, criatividade e sentido no pensamento de Winnicott. Rio de Janeiro: Garamond, 2014, p. 44.

${ }^{108}$ Ibid., p. 47.

${ }^{109}$ Ibid., p. 50.

${ }^{110}$ Ibid., p. 48.
} 
Compreende-se, nesse sentido, que o meio carcerário, ao contrário do esperado pelas disposições legais, demonstra-se apto tão somente a imprimir marcas indeléveis na construção do psiquismo daqueles que nele constroem suas estéreis lembranças associadas à infância. A determinação em prol da atenção do melhor interesse da criança parece, então, ter sido negligenciada por nossa lei de execução penal, que ao mostrar-se condizente com a prática do aprisionamento por tabela demonstrou-se preocupada, apenas, em acentuar a invisibilidade que historicamente recai sobre as crianças pobres de nosso pais, estigmatizando-as ainda mais perante a sociedade e violando basilares direitos que tanto no plano interno, quanto no plano internacional são garantidos aos infantes.

Analisando os direitos que são negados às crianças no cárcere, inicialmente sublinha-se: i) o direito à liberdade ${ }^{111}$, que de acordo com o ECA compreende o direito de ir, vir e estar nos espaços públicos e comunitários, além do direito de participar da vida familiar e comunitária, sem qualquer modalidade de discriminação; ii) o direito à dignidade ${ }^{112}$, analisado sobre o prisma do direito a um tratamento digno e atencioso às múltiplas necessidades infantis; iii) o direito à vida privada e intimidade familiar $^{113}$, uma vez que às internas é vedada a autodeterminação maternal, devendo elas seguirem as normas institucionais acerca do modo que devem cuidar de seus filhos; iv) o direito a manter laços com familiares ${ }^{114}$; v) o direito à saúde ${ }^{115}$, que abrange o direito ao mais alto nível possível de saúde

\footnotetext{
${ }^{111}$ OEA. Convenção Americana sobre Direitos Humanos. Op. cit., art. 7; ONU. Convenção sobre os Direitos da Criança. Op. cit., art. 37; BRASIL. Lei n. 8069. Op. cit., arts. 15 e 16.

${ }^{112}$ OEA. Convenção Americana sobre Direitos Humanos. Op. cit., arts. 5 e 11; BRASIL. Lei $n$. 8069. Op. cit., art. 15.

113 OEA. Convenção Americana sobre Direitos Humanos. Op. cit., art 11; ONU. Pacto Internacional dos Direitos Civis e Políticos. Aprovado em 16 de dezembro de 1966, art. 17; BRASIL. Lei $n .8069$. Op. cit., art. 19.

${ }^{114}$ OEA. Declaração Americana dos Direitos e Deveres do Homem. Op. cit., art. 5; Convenção Americana sobre Direitos Humanos. Op. cit., arts. 11 e 17; ONU. Declaração Universal dos Direitos Humanos. Aprovada em 10 dez. 1948, arts. 12 e 16; Pacto Internacional dos Direitos Civis e Políticos. Op. cit., art. 17; Convenção sobre os Direitos da Criança. Op. cit., arts 9 e 27.

${ }^{115}$ ONU. Convenção sobre os Direitos da Criança. Op. cit., art. 24; Pacto Internacional sobre os Direitos Econômico, Social e Cultural. Aprovado em 16 de dezembro de 1966, art. 12; Declaração Universal dos Direitos Humanos. Op. cit., art. 25; BRASIL. Lei n. 8069. Op. cit., art. 7 .
} 
física e mental ${ }^{116}$; vi) o direito à educação ${ }^{117}$, violado uma vez que o ECA determina o atendimento em creches e pré-escolas às crianças de zero a seis meses e que a Lei de Diretrizes e Bases da Educação estabelece a alfabetização a partir dos seis anos e vii) o direito à atividades recreativas e culturais $^{118}$, que são substituídas pelo ócio total nos presídios.

Ao lado da violação dos direitos acima destacados, a estadia no cárcere parece ser capaz de comprometer o direito à vida ${ }^{119}$ das crianças encarceradas, já que repercute no desenvolvimento dos infantes e produz cicatrizes que ficarão entranhadas no psiquismo destes. Neste sentido, o escritório argentino da Unicef indica que: "de forma complementar deve levar-se em conta que a privação de liberdade de uma criança junto com sua mãe afeta o seu direito à vida, uma vez que não é garantido na máxima medida possível seu desenvolvimento, devido a sua permanência em um meio onde é vulnerável a sofrer prejuízos ou abusos"120.

Outro importante direito que se encontra frontalmente violado com a permanência de crianças nos presídios é o direito à igualdade. Na medida em que os filhos das detentas são encaminhados aos presídios em razão de atos praticados por suas genitoras, passando, em virtude destes, a ter uma infância marcada por conceitos e experiências absolutamente inapropriados ao desenvolvimento infantil, atesta-se que estas crianças estão sendo preteridas, quando comparadas com as demais crianças, filhas de mães que não encontram-se cumprindo pena privativa de liberdade.

Identifica-se, nestes termos, violação expressa ao art. 2.2 da Convenção sobre os Direitos da Criança, que prevê que: “os Estados Partes tomem todas as medidas adequadas para que a criança seja efectivamente protegida contra todas as formas de discriminação ou de sanção decorrentes

\footnotetext{
${ }^{116}$ ONU. Comitê Direitos Econômicos Sociais e Culturais. Observação Geral n. 14. Aprovada no 22 período de Sessões das Nações Unidas em 2000, parágrafo 1.

117 ONU. Convenção sobre os Direitos da Criança. Op. cit., art. 28; BRASIL. Constituição da República. Op. cit., art. 208; Lei n. 8069. Op. cit, art. 28 e 54, IV; Lei 9394, de 20 de dezembro de 1996, art. 32.

${ }^{118}$ ONU. Convenção sobre os Direitos da Criança. Op. cit., art 31.

${ }^{119}$ Ibid., art. 6.

${ }^{120}$ UNICEF. Escritório da Argentina. Op. cit., p. 7. Tradução livre do espanhol.
} 
da situação jurídica, de atividades, opiniões expressas ou convicções de seus pais, representantes legais ou outros membros da sua família”.

Por fim, imperioso se faz ressaltar que a prática do encarceramento por tabela viola direito fundamental previsto no artigo 5, XLV de nossa Constituição Federal, que afirma que a pena não pode passar da pessoa do condenado. Trata-se, pois, do princípio da intranscendência penal ${ }^{121}$, que uma vez desrespeitado, nos termos firmados por Eugênio Zaffaroni, importa na inconstitucionalidade da pena imposta. Nas palavras do autor:

Embora exista um consenso no sentido de que é inevitável que parte da pena seja sofrida pela família e por outras pessoas, o nível tolerável de transcendência é ultrapassado em alguns casos concretos, como quando a pena aplicada se traduz em uma situação de desamparo para terceiros, produzindo consequências pessoais praticamente irreversíveis. Entende-se que nestes casos de transcendência extraordinária a terceiros, o princípio da intranscendência deve prevalecer, caso contrário a pena imposta seria inconstitucional. ${ }^{122}$

Conclui-se, a partir do exposto, que a permanência de crianças no cárcere na companhia de suas genitoras não atende ao principio do interesse superior infantil. Nestes termos, atesta-se a incompatibilidade da nossa Lei de Execução Penal com os standards jurídicos de proteção da criança, o que nos leva a procurar outras formas de enfrentar o tema, que demonstrem-se aptas a garantir a plenitude dos direitos dos infantes e de suas mães, atendendo ao postulado da especial proteção que recai sobre estes e tentando, deste modo, reverter a atual configuração social e jurídica, que lança ao desabrigo da mais pálida proteção crianças em seus primeiros estágios de vida e mulheres no exercício da maternidade.

\footnotetext{
${ }^{121}$ OEA. Convenção Americana sobre Direitos Humanos. Op. cit., art. 5.3.

${ }^{122}$ ZAFFARONI, E. Raúl. Derecho Penal, Parte General. Buenos Aires: Ediar Sociedad Anónima Editora, Comercial, Industrial y Financiera, 1999, p. 955. Tradução livre do espanhol.
} 


\section{Quarto Capítulo: A prisão domiciliar como medida necessária para garantir o melhor interesse da criança}

\subsection{Priorização dos direitos da criança sobre os demais direitos em pauta:}

A problemática que recai sobre os filhos das mulheres aprisionadas, longe de ser facilmente solucionada, depende de uma análise séria e comprometida de todos os direitos e interesses que envolvem a questão. Se de um lado temos um direito estatal legítimo de exercer sua pretensão punitiva penal diante do cometimento de um delito por uma mulher, de outro temos uma gama de direitos infantis e gestacionais, que não podem ser esvaziados. Assim, imperioso admitir-se que no momento em que a mulher presa passa a acolher em seu ventre uma nova vida, novos interesses, direitos e prioridades entram em jogo, devendo ser apreciados.

Inúmeras soluções despontam para atender à controvérsia. Contudo, muito além de determinar a permanência ou não de crianças no cárcere, deve-se levar em consideração que múltiplos fatores devem estar presentes a fim de que o direito ao desenvolvimento integral infantil seja satisfeito. Nestes termos, mais do que conceder um desfecho para a causa, mostra-se imprescindível que se encontre a saída que represente o melhor interesse da criança e que atenda integralmente os direitos dos infantes.

Inicialmente, destaca-se a inviabilidade da separação das detentas mães e de seus filhos em estágios iniciais de vida. O direito à lactação da mulher privada de liberdade, além de positivado na Constituição Federal e no ECA, deriva dos postulados firmados no direito internacional, relacionados à especial proteção infantil. Ademais, conforme ressalta a autora argentina Laura Noemí Lora, a referida separação é capaz de causar consequências traumáticas às crianças. Nas palavras da autora, "diversos estudos têm indicado que as filhas $\mathrm{e}$ filhos de mulheres presas experimentam (quando separados de suas mães) diversos problemas 
psicossociais: depressão, hiperatividade, comportamento agressivo ou dependente, retraimento, regressão, problemas de alimentação, dentre outros, considerando mães e crianças em estágio inicial de vida"123.

Na mesma direção, Maria Regina Fay de Azambuja, procuradora de justiça do Rio Grande do Sul, indica que "as crianças, cujos pais se encontram presos, podem apresentar uma variedade de emoções, que incluem desde medo, ansiedade, raiva, tristeza, solidão e culpa"124.

Ressalta-se, ainda, posicionamento da Comissão e da Corte Interamericana de Direitos Humanos, que têm entendido que situações em que crianças se veem separadas de seus genitores em virtude de uma atuação atribuível ao Estado, como é o caso da privação de liberdade em razão do ius puniendi penal, geram uma violação não apenas ao direito à proteção familiar, mas também ao direito à identidade das crianças ${ }^{125}$.

Depreende-se, nesta conjuntura, a importância da relação entre mãe e bebê para a construção da identidade da criança e para a garantia de seus direitos. O Conselho Nacional de Política Criminal e Penitenciária, neste sentido, afirma em sua Resolução n. 3 de 2009 que "a presença da mãe (...) é considerada fundamental para o desenvolvimento da criança, principalmente no que tange à construção do sentimento de confiança, otimismo e coragem, aspectos que podem ficar comprometidos caso não haja uma relação que sustente essa primeira fase do desenvolvimento"126.

O pediatra e psicanalista Winnicott contribui sobremaneira ao tema ao analisar a relação entre mães e bebês, frisando a relevância da figura materna para a saúde mental da criança e, ainda, para a construção de seu caráter, de sua personalidade e de sua criatividade. Nas palavras do autor:

Do ponto de vista da saúde mental, a mãe (se agir de forma adequada) estará também criando os fundamentos da força de caráter e da riqueza de personalidade

\footnotetext{
${ }^{123}$ LORA, Laura Noemí. Op. cit., p. 17. Tradução livre do espanhol.

${ }^{124}$ AZAMBUJA, Regina Fay. Os bebês filhos de mães que cumprem pena privativa de liberdade. Revista Gênero e Direito, 2013. ISSN 2179-7137, p. 60. Disponível em: http://periodicos.ufpb.br/ojs/index.php/ged/article/view/16947/9647. Acesso em: 03/11/14. ${ }^{125}$ OEA. Direito da Criança à Família. Op. cit., p. 23.

${ }^{126}$ CNPCP. Resolução número 03. Op. cit., artigo 2.
} 
do individuo. A partir de tal base positiva, o individuo tem, com o passar do tempo, uma oportunidade de lançar-se no mundo de uma forma criativa, e de desfrutar e usar tudo aquilo que o mundo tem a lhe oferecer, inclusive o legado cultural. Infelizmente, é uma grande verdade que, se uma criança não começar bem, então poderá não desfrutar do legado cultural e a beleza do mundo não passará de um colorido torturante, impossível de desfrutar. ${ }^{127}$

O pediatra inglês chama atenção para outro ponto central, qual seja, a importância da amamentação. De acordo com ele, a comunicação firmada entre mãe e bebê no momento da amamentação é fundamental para a solidificação do potencial infantil de se relacionar com o outro. Neste sentido, a amamentação mostra-se essencial à saúde infantil e para o estabelecimento da capacidade da criança de relacionar-se com os objetos e com o mundo ${ }^{128}$, além de estar atrelada à propensão à felicidade. Winnicott afirma, acerca do tema, que "não estamos apenas preocupados com a doença ou com distúrbios psiquiátricos; estamos preocupados com a riqueza da personalidade, com a força do caráter e com a capacidade de ser feliz, bem como com a capacidade de revolucionar e rebelar-se"129.

Firma-se, a partir da perspectiva acima anunciada, conclusão acerca da imperiosa relação entre mãe e bebê, que é, até mesmo, privilegiada por nossa Lei de Execução Penal. Esta, contudo, dispõe que o convívio materno deve se dar no interior dos muros das penitenciárias nacionais e, conforme atestado, esta solução contraria o postulado do interesse superior infantil na medida em que representa a violação de inúmeros direitos fundamentais das crianças e que não concede a devida proteção às mães e seus filhos.

Compreende-se, nestes termos, que o legislador deixou de priorizar o interesse infantil, agindo de forma contrária aos postulados do direito internacional dos direitos humanos. O escritório argentino da Unicef, acerca do tema, indica que "é necessário ressaltar que toda tensão existente entre os direitos da criança e o interesse público - neste caso, o interesse do Estado no cumprimento da pena ou medida cautelar no meio carcerário -

\footnotetext{
${ }^{127}$ WINNICOTT, Donald W. Os bebês e suas mamães. Tradução de CAMARGO, Jefferson Luiz. 3 edição. São Paulo: Martins Fontes, 2006, p. 20.

${ }^{128}$ Ibid., p. 55.

${ }^{129}$ Ibid., p. 20.
} 
deve ser solucionada aplicando o standard jurídico do interesse superior da criança, que levará sempre a privilegiar os direitos dos menores de idade" ${ }^{\prime 130}$. Este direcionamento, assim como todos os outros ratificados no âmbito internacional, encontra-se, todavia, frontalmente desrespeitado por nossa legislação pátria, que parece insistir no aprisionamento como solução para a conflitividade da sociedade, independentemente do peso social que este caminho possa importar.

Assim, após a constatação do descarte da viabilidade da separação entre mães e filhos e, ademais, da identificação de todos os reflexos negativos que o cárcere é capaz de provocar em crianças com tenra idade, deve-se atentar a novos caminhos jurídicos, hábeis a conciliar o interesse social do Estado no cumprimento da pena por parte da mulher condenada e, ao mesmo tempo, o interesse superior da criança, filha da apenada.

Ao se analisar o tema, vislumbra-se uma solução, já consagrada no direito comparado e amplamente defendida internacionalmente, que garante a relação entre mãe e filho - longe do âmbito prisional e do estigma social que importa a permanência no cárcere de crianças que não possuem qualquer relação com o delito praticado por suas genitoras -, sem abrir mão do cumprimento da pena por parte da mulher condenada. Trata-se, pois, da concessão de prisão domiciliar para a mulher que deu à luz, a fim de que esta permaneça com seu filho em sua residência, cumprindo sua pena e atendendo às demandas infantis.

Nesta direção, as Regras de Bangkok, aprovadas no âmbito da ONU, ao versarem sobre o tratamento a ser concedido às mulheres privadas de liberdade, reconhecem a possibilidade da suspensão da reclusão da detenta que possui filhos menores, por um período razoável, em função do interesse superior da criança $^{131}$. A partir desta disposição, diversas outras passaram a

\footnotetext{
${ }^{130}$ UNICEF. Escritório da Argentina. Op. cit., p. 7. Tradução livre do espanhol. 131 ONU. Regras de Bangkok. Op. cit., Regra 2.2 versa que: "Prior to or on admission, women with caretaking responsibilities for children shall be permitted to make arrangements for those children, including the possibility of a reasonable suspension of detention, taking into account the best interests of the children".
} 
ser firmadas no âmbito internacional, delineando a prisão domiciliar, no lugar da suspensão da pena, como o meio de melhor solucionar a questão.

Resgatando-se as disposições da Convenção sobre os Direitos da Criança temos que o encarceramento de uma criança apenas pode ser admitido como medida de último recurso, na hipótese de não haver nenhum outro meio menos gravoso para equacionar a temática ${ }^{132}$. Ora, sendo viável a concessão de prisão domiciliar para a detenta, não pode-se cogitar em colocar uma criança na prisão, ao invés de fazer com que sua mãe cumpra pena longe do âmbito carcerário. O escritório argentino da Unicef, nesta direção, conclui que "não se justifica a privação da liberdade de uma criança junto com sua mãe no intuito de proteger seu direito à família e a proibição de separação dos pais, uma vez que é possível a adoção de outra medida estatal menos lesiva que assegure estes fins"133.

Sublinha-se, ademais, a concessão de prisão domiciliar como a saída mais adequada a preservar o fortalecimento do vínculo familiar. A referida medida, ao ser adotada pelo Estado, faz com este se alinhe à demanda por proteção, que deve ser perseguida na medida em que, conforme firmado pelo direito internacional e pela legislação interna, o Estado ocupa uma posição de garante frente à família, devendo, em razão disto, adotar medidas positivas que efetivem uma proteção real e integral ao seio familiar. Laura Noemí Lora, ao versar sobre a temática, ratifica o posicionamento até então desenvolvido, indicando que:

Deve-se recorrer a medidas, como a prisão domiciliar, que assegurem igualmente o contato com a mãe e que evitem a interrupção do vínculo filial, o desmembramento do grupo familiar e o confinamento ou institucionalização de crianças. Desta forma, se garantirá tanto o cumprimento da finalidade cautelar ou punitiva da medida coercitiva, quanto a manutenção do núcleo familiar. ${ }^{134}$

\footnotetext{
${ }^{132}$ ONU. Convenção sobre os Direitos da Criança. Op. cit., art 37 versa que "Los Estados Partes velarán por que: [...] b) Ningún niño sea privado de su libertad ilegal o arbitrariamente. La detención, el encarcelamiento o la prisión de un niño se llevará a cabo de conformidad con la ley y se utilizará tan sólo como medida de último recurso y durante el período más breve que proceda".

${ }^{133}$ UNICEF. Escritório da Argentina. Op. cit., p. 8. Tradução livre do espanhol.

${ }^{134}$ LORA, Laura Noemí. Op. cit., p. 14. Tradução livre do espanhol.
} 
O escritório argentino da Unicef, também nesta diretriz, elenca a prisão domiciliar como a medida mais adequada para garantir os direitos das crianças e adequar os ordenamentos jurídicos nacionais às disposições do direito internacional dos direitos humanos. Nos termos do órgão:

\begin{abstract}
Sempre que mostrar-se necessária a aplicação de uma pena privativa de liberdade ou de uma medida cautelar a mulheres grávidas ou mães de crianças menores de idade, deverá ser outorgada prisão domiciliar ou outra medida alternativa à prisão. Este é o caminho que deve ser perseguido a fim de que se resguardem as normas do direito internacional dos direitos humanos, como o direito à vida, à saúde, à intranscendência da pena, bem como os princípios que exigem cuidados especiais às crianças. ${ }^{135}$
\end{abstract}

A alternativa pela prisão domiciliar já foi suscitada e debatida em encontros de juristas no Brasil, o que demonstra nossa preocupação com o tema, sendo, contudo, imperioso que se avance no seu pleito e deliberação. Conforme destacado por Sandra Maciel, Adriane Matos e Carmem Lúcia, a questão foi abordada no "encontro dos Conselhos da Comunidade, realizado em Salvador, em 2008. A proposta foi de que fosse permitida prisão domiciliar e monitoramento eletrônico para as mães grávidas e lactantes em substituição à pena de prisão" ${ }^{\text {"136 }}$. Recentemente, no âmbito da Escola de Magistratura do Estado do Rio de Janeiro, profissionais do direito se debruçaram sobre o tema na palestra intitulada "Exercício de maternidade por mulheres em situação de prisão" ${ }^{137}$.

Assevera-se, em última análise, a importância da conversão da pena privativa de liberdade em prisão domiciliar a fim de que se garanta a dignidade das crianças encarceradas e das mulheres que experimentam a maternidade no cárcere. A anunciada medida, muito além de equacionar os direitos das mulheres e de seus filhos e os interesses estatais, desponta como técnica imprescindível para garantir a plenitude dos direitos infantis,

\footnotetext{
${ }^{135}$ UNICEF. Escritório da Argentina. Op. cit., p. 8. Tradução livre do espanhol.

${ }^{136}$ ALMEIDA, Sandra, MATTOS, Carmem e ARAUJO, Adriane. Op. cit., p. 13.

${ }^{137}$ EMERJ. Fórum Permanente de Direitos Humanos, 51 Reunião, dia 01/09/14. Palestrantes: CASARA, Rubens; ANDRADE, Bruna e BRAGA, Ana Gabriela. Convite disponível em: http://www.eventos.ufrj.br/?event=exercicio-de-maternidade-por-mulheres-em-situacao-de-prisao. Acesso em: 03/11/14.
} 
sua especial proteção e, conforme destacado, primar pela dignidade dos envolvidos. O princípio da dignidade humana, fundamento de nosso Estado Democrático de direito, requer que se atente às especificidades dos infantes e, acima de tudo, se reconheça a incompatibilidade entre nossos presídios, marcados por severas violações de direitos fundamentais, e o desenvolvimento de uma nova vida, relacionada a novos sonhos e novos anseios. Nestes termos, admitir a permanência de crianças no cárcere importa em negar-lhes dignidade e direitos. Juliana Araújo Lemos da Silva Machado, defensora pública do Estado de São Paulo, ressalta, neste sentido, a correlação entre o tema e o princípio da dignidade humana, dispondo que:

\begin{abstract}
Negar à mulher presa o direito ao devido acompanhamento médico pré, peri e pós-natal e o direito de cuidar e amamentar seus filhos é, sem dúvida alguma, impingir-lhe o cumprimento de uma pena desumana, cruel, que contraria todos os princípios de humanização das sanções penais, de modo que, em última instância, o que está em jogo é a dignidade da pessoa presa, violada em seus direitos fundamentais por uma circunstância a que não deu causa e pela qual não pode ser penalizada: a notória falha do Estado na manutenção de um sistema prisional caótico, que não resguarda os mais elementares direitos dos cidadãos encarcerados. ${ }^{138}$
\end{abstract}

Após discorrer sobre a conversão da pena privativa de liberdade em prisão domiciliar como medida necessária a garantir o melhor interesse da criança e a especial proteção que deve recair sobre a mulher nos períodos de gestação e amamentação, se passará à apresentação da abordagem do tema nos países latino-americanos e, em seguida, serão enaltecidos os avanços atestados em nossa jurisdição interna acerca da questão.

\footnotetext{
${ }^{138}$ MACHADO, Juliana Araújo. A presa gestante ou lactante tem direito a prisão domiciliar especial quando não houver vaga em estabelecimento penal adequado. Defensoria Pública do Estado de São Paulo - DPESP, p. 10. Disponível em: http://www.cursofmb.com.br/arquivosprof/gestante\%20e\%20prisão\%20domiciliar.pdf. Acesso em: 27/10/2014.
} 


\subsection{Breve panorama legal da América Latina:}

A ampliação das hipóteses de cabimento da prisão domiciliar, a fim de que estas passem a contemplar a mulher que está em exercício da maternidade, embora aparentemente distante da realidade jurídica brasileira, em absoluto não pode ser tida como uma medida utópica ou inalcançável. Ao se analisar o ordenamento jurídico dos nossos vizinhos latino-americanos nota-se que diversos países já consagram medidas especiais às mulheres privada de liberdade gestantes e com filhos pequenos.

Destaca-se, neste sentido, cinco realidades jurídicas - da República Dominicana, do Peru, da Colômbia, da Argentina e da Bolívia comprometidas com as prospectivas anunciadas no direito internacional, que devem servir de norte para a alteração de nossa legislação interna.

No plano da República Dominicana, observa-se que o Código Processual Penal foi alterado, em 19 de julho de 2002, pela Lei n. 76/02, de modo que seus artigos 234 e 342 passassem a se curvar à especial proteção que deve recair sobre as mulheres grávidas e mães de filhos pequenos ${ }^{139}$. Nestes termos, seu artigo 342 passou a dispor que o juiz, ao conceder uma ordem de prisão para uma mulher em período de gestação ou lactância, deve determinar o seu cumprimento total ou parcial no domicílio da imputada, levando em consideração suas condições particulares. Frisa-se acerca da norma trecho firmado pela Suprema Corte de Justiça dominicana:

\footnotetext{
De acordo com o Art. 342 do Código de Processo Penal, a fixação da pena por parte do tribunal de mérito deve estar sujeita a condições especiais de cumprimento, determinadas em razão das características individuais do imputado ou imputada, em conformidade com o princípio orientador da humanização da pena, que determina a imposição de um regime especial para o cumprimento da pena nos seguintes casos: (...) Quando a imputada encontre-se em estado de gestação ou lactância; (...) O cumprimento da pena imposta nos casos mencionados pode ser total ou parcialmente realizado como indicado na sentença como são: no domicílio do condenado ou condenada; em um centro de saúde
}

\footnotetext{
${ }^{139}$ REPÚBLICA DOMINICANA. Lei n. 76/02, que estabelece o Código Processual Penal da República Dominicana, arts. 234 e 342. Disponível em: http://ojd.org.do/Normativas/PENAL\%20ORDINARIO/Reglamentos/Res.\%20No.\%202962005,\%20Reglamento\%20Juez\%20de\%201a\%20Ejecución\%20CPP.pdf. Acesso em: 28/10/14.
} 
mental, geriátrica ou de desintoxicação, conforme ordene a sentença condenatória irrevogável. ${ }^{140}$

O artigo 234, por sua vez, proíbe a decretação de prisão preventiva contra mulheres grávidas ou em estado de amamentação ${ }^{141}$. Esta disposição representa louvável iniciativa do Estado dominicano, na medida em que reproduz standard firmado no direito internacional, que indica que o uso de medida privativa de liberdade em desfavor de mulheres gestantes e lactantes deve ser restritivo. Neste sentido, ressalta-se direcionamento firmado no Oitavo Congresso das Nações Unidas sobre a Prevenção de Delitos e o Tratamento de Delinquentes, que dispõe que "uso da pena de prisão para pessoas de certas categorias, como as mulheres grávidas ou mães de bebês pequenos, deve ser restritivo e deve ser feito um esforço especial para evitar-se o uso de prisão como sanção para tais categorias"142.

O Código Processual Penal do Peru também foi alterado, pelo Decreto Legislativo n. 957, em 2004, de modo que o direito peruano se adequasse às exigências dos direitos humanos das mulheres gestantes e lactantes. Nesse contexto, seu artigo 290 passou a determinar, em seu inciso I, letra “d”, a imposição de prisão domiciliar, ainda que se trate de medida preventiva e não definitiva, para a mulher gestante. Neste panorama, a

\footnotetext{
${ }^{140}$ REPÚBLICA DOMINICANA. Extratos de las Resoluciones de Interés General de la Suprema Corte de Justicia 2005. República Dominicana: Editora Gaceta, 2006, p. 12. Disponível em: http://www.suprema.gov.do/documentos/PDF/publicaciones/libros/2005/estractos_resoluciones_sc j_2005.pdf. Acesso em: 04/11/14. Tradução livre do espanhol.

${ }_{141}$ REPÚBLICA DOMINICANA. Lei n. 76/02. Op. cit., artigo 234 dispõe que "Prisión preventiva. Además de las circunstancias generales exigibles para la imposición de las medidas de coerción, la prisión preventiva sólo es aplicable cuando no pueda evitarse razonablemente la fuga del imputado mediante la imposición de una o varias de aquellas que resulten menos gravosas para su persona. No puede ordenarse la prisión preventiva de una persona mayor de setenta años, si se estima que, en caso de condena, no le es imponible una pena mayor a cinco años de privación de libertad. Tampoco procede ordenarla en perjuicio de mujeres embarazadas, de madres durante la lactancia o de personas afectadas por una enfermedad grave y terminal".

${ }^{142}$ ONU. Oitavo Congresso das Nações Unidas sobre a Prevenção de Delito e o Tratamento do Delinquente. La Habana, 27 de agosto a 7 de setembro de 1990. Documento ONU A/Conf. 144/28, Rev. 1, Cap. C, Resolución 19, (c) 5 (f) (em inglês). Disponível em: http://www.unodc.org/documents/congress//Previous_Congresses/8th_Congress_1990/028_ACO NF.144.28.Rev.1_Report_Eighth_United_Nations_Congress_on_the_Prevention_of_Crime_and_t he_Treatment_of_Offenders.pdf. Acesso em: 03/11/14. Tradução livre do espanhol.
} 
norma prevê que: "Será imposta prisão domiciliar quando, ainda que a prisão seja preventiva, o imputado: (...) d) For uma mulher gestante" ${ }^{, 143}$.

No âmbito da Colômbia igualmente verifica-se disposições legislativas atentas aos cuidados especiais que devem ser atribuídos à mulher no exercício da maternidade. Neste cenário, o Código de Procedimento Penal colombiano, alterado pela Lei n. 1.142 de 2007, passou a firmar, em seu artigo 314, a substituição da prisão preventiva por recolhimento domiciliar para as mulheres grávidas que estiverem a dois meses do parto, para aquelas que tiverem dado à luz há menos de seis meses e, ainda, para aquelas que tiverem filhos menores de doze anos que dependam de seus cuidados. A lei firma, nesta última hipótese, o cabimento de prisão domiciliar também para o homem que for responsável pelos cuidados de um filho menor. Nos termos firmados pelo dispositivo legal:

Artigo 314: A prisão preventiva em estabelecimento prisional pode ser substituída pelo local de residência nos seguintes casos: (...) 3. Quando a imputada ou acusada estiver há dois meses ou menos da data do parte. Igual direito terá durante os seis meses seguintes ao nascimento. (...) 5. Quando a imputada ou acusada for chefe da família de filho menor de idade ou que sofra de incapacidade permanente, desde que a criança ou incapaz dependa de seus cuidados. Na ausência da mãe, o pai que a substituir terá o mesmo benefício. ${ }^{144}$

O ordenamento jurídico argentino também sofreu recentes alterações a fim de que passasse a atender aos direitos das mulheres aprisionadas que ocupem o papel de mães. Nestes termos, a Lei de Execução da Pena Privativa de Liberdade da Argentina, com a aprovação da Lei 26.472 no ano de 2008, passou a indicar, em seu artigo $32^{145}$, o cabimento de prisão domiciliar para a mulher grávida ou mãe de filho menor de cinco anos de

143 PERU. Código Processual Penal do Peru, art. 290. Disponível em: http://concurso.ceperj.rj.gov.br. Acesso em: 28/10/14. Tradução livre do espanhol.

${ }^{144}$ COLÔMBIA. Código de Procedimento Penal da Colômbia, art. 314. Disponível em: http://procedimientopenalcolombiano.blogspot.com.br/2010/01/art314-sustitucion-de-ladetencion.html. Acesso em: 28/10/14. Tradução livre do espanhol.

${ }^{145}$ ARGENTINA. Lei de Execução da Pena Privativa de Liberdade, art. 32 dispõe que: “ El Juez de ejecución, o juez competente, podrá disponer el cumplimiento de la pena impuesta en detención domiciliaria: (...) e) A la mujer embarazada; f) A la madre de un niño menor de cinco (5) años o de una persona con discapacidad, a su cargo". Disponível em: http://www.infoleg.gov.ar/infolegInternet/anexos/145000-149999/149566/norma.htm Acesso em: 28/10/14. 
idade que dependa de seus cuidados. O fundamento para a mudança, conforme enalteceram os discursos sediados na Câmara dos Deputados argentina, foi a compatibilização da legislação interna com a Convenção das Nações Unidas sobre os Direitos da Criança. Neste sentido, sublinha-se manifesto da deputada Marcela Rodríguez acerca da nova lei:

Isso não significa eliminar uma sanção penal a pessoas que efetivamente a merecem; a única coisa que isto implica é que o interesse social não pode prevalecer sobre os direitos à vida, à saúde, à integridade ou à dignidade dos condenados ou processados. Menos ainda pode-se ter crianças em condição de detenção, uma vez que esta prática viola todos os direitos contemplados na Convenção Internacional sobre os Direitos da Criança. ${ }^{146}$

Por fim, ressalta-se as disposições do Código de Procedimento Penal da Bolívia que, a partir da aprovação da Lei 316 em dezembro de $2012^{147}$, passou a indicar em seu artigo 431 que o juiz da execução penal, diante da determinação do cumprimento de uma pena privativa de liberdade por parte de mulheres gestantes ou mães de filhos menores de um ano, deverá dispor das medidas cautelares convenientes, de modo que a prisão não venha a se caracterizar. Ademais, seu artigo 232 passou a indicar que a determinação de uma prisão preventiva em desfavor de mulheres gestantes ou mães de crianças de até um ano de idade apenas pode ser levada a cabo quando nenhuma outra medida alternativa - dentre elas a prisão domiciliar - puder ser aplicada. Trata-se da positivação do uso restritivo da privação de liberdade das mulheres gestantes e em exercício de maternidade, nos termos delineados pelo direito internacional dos direitos humanos.

\footnotetext{
${ }^{146}$ RODRIGUEZ, Marcela. Debate realizado na Câmara de Deputados, na 22 Reunião da 14 Sessão Ordinária. Disponível em: http://www1.hcdn.gov.ar/sesionesxml/item_param.asp?per=125\&r=22\&n=20\&orador=RODRIGU EZ\&nombres=MARCELA\%20VIRGINIA. Acesso em: 04/11/14. Tradução livre do espanhol.

${ }^{147}$ BOLIVÍA. Código de Procedimento Penal, artigo 431 dispõe que: "Antes de la ejecución de una pena privativa de libertad, el juez o tribunal que dictó la condena diferirá la ejecución de la pena y dispondrá las medidas cautelares convenientes que aseguren su ejecución, en los siguientes casos: 1. Cuando deba cumplirla una mujer embarazada o que tenga un hijo menor de un año al momento de la ejecutoria de la sentencia; 2. Cuando el condenado se encuentre gravemente enfermo y la inmediata ejecución ponga en peligro su vida, según el dictamen médico forense"; artigo 232 dispõe que: " Tratándose de mujeres embarazadas y de madres durante la lactancia de hijos menores de un año, la detención preventiva sólo procederá cuando no exista ninguna posibilidad de aplicar otra medida alternativa". Disponível em: http://www.lexivox.org/norms/BOL-N316.xhtml. Acesso em: 28/10/14.
} 
A partir da análise do panorama legal dos países da América Latina, próximos do Brasil, constata-se nosso atraso legislativo e impõe-se urgente alteração de nossa Lei de Execução Penal, de modo que esta deixe de representar uma afronta direta e real aos direitos das detentas gestantes e de seus filhos menores, passando a se adequar aos avanços proclamados no cenário internacional.

\subsection{Avanços verificados na jurisdição interna:}

No âmbito interno verifica-se alguns avanços, tanto na jurisprudência como na legislação penal e de execução penal, que demonstram o despertar de uma preocupação de nossa jurisdição pátria para com os direitos das presidiarias em período de gestação e de seus filhos menores. Em seguida, se passará a analisar cada uma destas medidas a fim de propugnar por ampliações e por uma verdadeira harmonização de nosso ordenamento às referências humanitárias firmadas no direito internacional.

Preliminarmente, vale destacar que nossa Lei de Execução Penal admite, em seu artigo 117, inciso IV, a concessão de prisão domiciliar para a mulher condenada gestante que for beneficiária de regime aberto. Esta outorga adstrita ao regime aberto, todavia, acaba por esvaziar o direito das apenadas, uma vez que, conforme salientado no segundo capítulo, hoje a maioria das mulheres são presas em virtude de tráfico de drogas ${ }^{148}$, que

\footnotetext{
${ }^{148}$ LEMGRUBER, Julita. Pronunciamento no Encontro Nacional sobre o Encarceramento Feminino do CNJ, 2011, indicando que: "o tráfico de drogas como responsável por $65 \%$ das prisões de mulheres brasileiras entre 2006 e 2011”. In: MONTENEGRO, Manuel Carlos. População Carcerária feminina aumenta $42 \%$ nos últimos cinco anos. CNJ Online. Disponível em: http://www.cnj.jus.br/noticias/cnj/25998-populacao-carceraria-feminina-aumenta-42-nos-ultimoscinco-anos\#ad-image-0. Acesso em: 03/11/14. Ver também: BRASIL. Lei n. 11.343/06, art. 33. Crime de tráfico de drogas, com pena de reclusão de 5 a 15 anos e pagamento de 500 (quinhentos) a 1.500 (mil e quinhentos) dias-multa.
} 
impõe pena de reclusão de mais de quatro anos de privação de liberdade, sendo, portanto, incompatível com o regime aberto ${ }^{149}$.

Paralelamente, nosso Código Penal, após a aprovação da Lei 12.403 de 2011, passou a prever, em seu artigo 318, incisos III e IV, a substituição da prisão preventiva pela domiciliar quando o agente for "imprescindível aos cuidados especiais de pessoa menor de seis anos de idade" ou "gestante a partir do sétimo mês de gravidez ou sendo esta de alto risco".

Depreende-se, a partir dos dispositivos acima destacados, que nosso legislador inclina-se à proteção das mulheres gestantes e preocupa-se com a situação das crianças menores que venham a ter seus genitores aprisionados. Contudo, na medida em que este cuidado apenas recais sobre as mulheres presas preventivamente ou, quando condenadas, beneficiárias de regime aberto, conclui-se que nossos avanços legislativos ainda são muito tímidos e, por isso, insuficientes para atenderem de forma plena os direitos infantis e das mulheres em exercício de maternidade.

O Poder Judiciário, ao debruçar-se sobre a causa, já confirmou esta limitação legislativa, tendo ampliado, em inúmeros casos concretos ${ }^{150}$, o rol de cabimento da prisão domiciliar. Neste sentido, ressalta-se julgamento do Habeas Corpus n. 115.941/PE pelo Superior Tribunal de Justiça. Ao apreciar o writ, que versa sobre o pleito de conversão de medida privativa de liberdade em reclusão domiciliar por parte de uma mulher que, há época dos fatos, possuía um filho recém-nascido, que contava com apenas quatro meses e que dependia de seus cuidados e de sua lactação, o Tribunal

\footnotetext{
${ }^{149}$ BRASIL. Decreto Lei n. 2.848 de 7/12/40, que institui o Código Penal, art. art. 33, parágrafo 2, letra "c" dispõe sobre os regimes de cumprimento de pena: "o condenado não reincidente, cuja pena seja igual ou inferior a 4 anos, poderá, desde o início, cumpri-la em regime aberto".

${ }^{150}$ Exemplos de julgados em que o rol do Art. 117, LEP foi ampliado: STJ, HC 40748 MT 2004/0184477-4, Rel. Min. Paulo Medina, Brasília, 28/06/2005, ementa: "Processo Penal. Habeas Corpus. Prisão Preventiva. Paciente portador de doenças graves. Estado de saúde debilitado. Segregação. Prisão domiciliar. Requisitos. Flexibilização do art. 117 da Lei n. 7.210/84. Aplicação do princípio constitucional fundamental da dignidade da pessoa humana. Constituição Federal, art. 1, inciso III. Questão não suscitada em 2 grau. Pedido prejudicado. Ordem concedida ex officio"; STJ, HC no 110.569/MS, Rel. Min. Felix Fischer, Brasília, 04/06/2009; TJ/RS, Agravo em execução n. 70056569049, Porto Alegre, 28/11/13; TJ/SC, HC 37437 SC 2009.003743-7, Rel. Marli Mosimann Vargas, Florianópolis, 14/04/09.
} 
entendeu pela possibilidade da aplicação analógica do art. 117 da LEP, em nome do princípio da dignidade da pessoa humana, deferindo o pedido.

Inicialmente, a detenta que figura como autora da demanda teria sido encaminhada para presídio masculino em cidade diversa da que residia, o que lhe impedia a prestar a devida assistência ao seu filho e inviabilizava a amamentação deste, motivo pelo qual a saúde do bebê teria se deteriorado. O juízo de primeiro grau, ao pronunciar-se sobre o pedido, identificando a transferência da detenta para um presídio feminino, denegou a ordem, sob o argumento de que o crime teria ocorrido no local em que a prisão foi verificada, seguindo regra de processual que não poderia ser excepcionada.

$\mathrm{Na}$ sentença, o juízo chega a afirmar que as presas devem se contentar com a realidade das penitenciárias pernambucanas, não havendo que se falar em efetivação de direitos ou similares. Nos termos firmados pelo juiz: "a cadeia pública feminina da cidade de Verdejante, justamente por ser feminina, deve atender na medida da realidade do Sertão Pernambucano, as condições específicas da mulher, tal como a ocorrência de gestação ou de aleitamento materno que podem ocorrer em presas"151

A decisão foi confirmada no segundo grau e apenas no STJ a detenta teve o seu direito à lactação e a permanecer com seu filho garantido. Nesta oportunidade, a ministra relatora Maria Thereza de Assis Moura afirmou que "o interesse da administração da justiça também há que ser sopesado em relação ao interesse do menor lactente em ter a assistência da mãe

\footnotetext{
${ }^{151}$ STJ. HC. 115.941/PE, Rel. Ministra Maria Thereza de Assis Moura, Brasília, 03/08/09, ementa: "EXECUÇÃO PENAL. HABEAS CORPUS.1. PRESA PROVISÓRIA. NECESSIDADE DE AMAMENTAÇÃO DE FILHO RECÉM-NASCIDO. DETENÇÃO EM COMARCA DIVERSA DE ONDE RESIDE E ONDE SE ENCONTRA A CRIANÇA. DIREITO CONSTITUCIONAL. RECONHECIMENTO. 2. APLICAÇÃO ANALÓGICA DO ART. 117 DA LEP. POSSIBILIDADE. MEDIDA EM NOME DA DIGNIDADE DA PESSOA HUMANA E PROPORCIONAL NO CASO CONCRETO. 3. ORDEM CONCEDIDA. 1. Mesmo às presas provisórias devem ser garantidas condições de permanecer com o filho no período de amamentação (artigo $5^{\circ}, \mathrm{L}, \mathrm{CR}$ ). Não é razoável que a paciente fique presa em comarca diversa da que residia com a criança, ainda mais se já se encontra condenada em primeiro grau e não mais subsiste qualquer interesse probatório na sua proximidade física com o local dos fatos. 2. É possível a aplicação analógica do artigo 117 da Lei 7.210/84, ao caso ora sob exame, mostrando-se proporcional e razoável que a paciente fique em regime domiciliar para dar maior assistência a seu filho, já que não há estabelecimento adequado para estas circunstâncias na Comarca de Juazeiro. 3. Ordem concedida para que a paciente seja colocada em prisão domiciliar até o trânsito em julgado da ação penal, devendo o juízo de primeiro grau estipular as suas condições".
} 
nestes primeiros anos de vida"152, tendo concluído que "é possível a aplicação analógica do artigo 117 da Lei 7.210/84, ao caso ora sob exame, mostrando proporcional e razoável que a paciente fique em regime domiciliar para dar maior assistência a seu filho" $" 153$.

A decisão acima elencada figura como um verdadeiro paradigma, que deve ser enaltecido a fim de que se passe a lidar de forma comprometida com os direitos das presas enquanto mães e de seus filhos, seres em desenvolvimento merecedores de cuidados especiais. Presencia-se, neste contexto, os primeiros passos de um caminho que urgentemente necessita ser percorrido, no intuito de que se reconheça a prisão domiciliar como um direito de todas as mulheres que vivenciam a maternidade no cárcere, independentemente da prisão destas ser preventiva ou definitiva, decretada em regime aberto, semiaberto ou fechado.

Propugna-se, neste sentido, que os direitos das mulheres gestantes e de seus filhos menores passem a ser valorizados e garantidos em sua plenitude. Com isto, defende-se a concessão de prisão domiciliar de forma ampla, de modo que esta alcance: i) as mulheres em período de lactância, ii) aquelas que tiverem filhos menores de seis anos ${ }^{154}$ que dependam exclusivamente de seus cuidados e iii) as gestantes, quando comprovado que a unidade prisional em que encontram-se cumprindo pena não possui atendimento pré-natal regular e de qualidade. Ademais, sublinha-se a importância do uso restritivo da prisão preventiva para as mulheres gestantes e mães de filhos pequenos, sendo imperioso que a privação de liberdade antes do trânsito em julgado apenas se verifique em casos excepcionalíssimos, quando a separação entre mãe e filho se mostrar imprescindível para atender ao interesse superior da criança.

\footnotetext{
${ }^{152}$ Ibid.

${ }^{153}$ Ibid.

${ }^{154}$ Optamos pelo marco de seis anos de idade seguindo as diretrizes fornecidas pelo legislador no artigo 318 do Código Penal.
} 


\section{Conclusão:}

Ao identificarmos nosso sistema penitenciário como o locus da ausência de direitos humanos, como o aposento de seres com humanidade reduzida, caracterizados pela invisibilidade e pela marginalização, atenta-se à extrema vulnerabilidade que dita seus interiores. Os sujeitos encarcerados, além de perderem sua liberdade, têm sua dignidade pulverizada e sua subjetividade extinguida. Neste contexto, evidencia-se uma distância abissal entre os direitos formalmente concebidos, atentos a todos os pormenores da vida intramuros, e a realidade fática, capaz de corromper e negar todas as garantias consagradas legalmente.

Conforme visualizado, embora já se tenha firmado um consenso, no âmbito da criminologia crítica, acerca da falência da instituição prisional, esta ainda ocupa o centro de nossa política criminal, abrigando, inclusive, crianças que não possuem qualquer relação com a criminalidade. Assim, apesar das mazelas e do potencial destrutivo, nossos presídios, de acordo com a LEP, devem acolher os filhos das apenadas que derem à luz no cárcere, crianças que ao nascerem serão encaminhadas para o interior dos muros do universo prisional, sendo obrigadas a conviverem com a rigidez e a disciplina inerentes ao cumprimento de pena privativa de liberdade.

A despeito da existência de um firme posicionamento atestado no plano internacional dos direitos humanos e no direito comparado, que determina a sobreposição dos direitos da criança sobre o direito do Estado de exercer o ius puniendi penal, a legislação pátria insiste em encarcerar crianças, passando por cima das diretrizes que impõem ao Estado o dever de primar pelo melhor interesse infantil e pela plenitude de seus direitos.

Abordar de forma séria a problemática das crianças que nascem no presídio, nos termos firmados, importa em relativizar o interesse estatal atrelado ao cumprimento de pena de prisão por parte da mulher que cometeu um delito, a fim de garantir os direitos das crianças, que merecem destaque e prioridade. Neste sentido, imperioso que nossa legislação de 
execução penal seja alterada, de modo a conceder prisão domiciliar para a mulher em exercício da maternidade, curvando-se à especial proteção que a esta deve ser concedida nos momentos do pré-natal, parto e lactação.

O presente trabalho, neste sentido, após delinear as especificidades atreladas à maternidade no interior do cárcere, pugna pelo reconhecimento da incompatibilidade existente entre os artigos 83 e 89 da LEP com os direitos das crianças, seres que devem permanecer no seio familiar e ter garantido todas as elementares necessárias ao seu pleno desenvolvimento. Assim sendo, deve ser assegurado ao infante o relacionamento com sua genitora pelo menos nos seus primeiros meses de vida e este contato deve ser verificado em um ambiente propenso ao desenvolvimento infantil. Inadmissível, portanto, que crianças continuem crescendo aprisionadas.

Afinal, como pode-se consentir que todas as descobertas, alegrias e desejos, marcados por um colorido cintilante quando vivenciados por crianças que estão, pela primeira vez, se posicionando diante do mundo se restrinjam à torturante rotina institucional de nossos presídios, locais que, muito mais do que prenderem, roubam vidas, experiências e toda a multiplicidade que nos renova a cada dia. Como tolerar que crianças troquem as ricas relações com o mundo e com familiares pela pobre visão quadrada que os presídios são capazes de oferecer? Muito longe de proteger estas crianças, nossa lei acaba por subtrair-lhes a infância, o momento lúdico da vida, que deve permear a memória e o imaginário dos adultos no futuro, para que estes tenham criatividade e a ousadia de pensar no novo, fora dos parâmetros e das regras pré-estabelecidas, que insistem em rotular e diminuir nossas potencialidades e riquezas.

Deseja-se, pois, que as crianças sejam consideradas em sua plenitude. Que fiquem livre de discriminações e que, assim, deixem de "por tabela" receberem a imposição de uma pena que não é a elas direcionada. Deseja-se que sejam resguardados os direitos delas de brincar, de crescer e inventar o universo que as rodeia, sem deixar que este, ao contrário, lhes imponha linguagens de mundo relacionados à estéril perspectiva do crime. 
E, ainda, idealiza-se que os internos de nosso sistema penitenciário deixem de figurar na posição do outro, do inimigo, passando a serem vistos como pessoas merecedoras da efetivação de todos os direitos que formalmente são a eles assegurados. Necessário que se repense nosso modelo punitivista penal, que pretende solucionar os conflitos sociais marginalizando e encarcerando ao invés de olhar para o cerne que existe por trás da desordem, atrelado à desigualdade e à violência, derivados dos períodos remotos, porém ainda presentes, da escravidão e da ditadura.

Neste cenário, compreender o presídio como instrumento de repressão social ${ }^{155}$, um bolsão de exclusão, um não-lugar no contexto de proteção dos direitos humanos leva-nos a propugnar a insurgência contra o intolerável ${ }^{156}$, o anseio por transformações e o avanço na perspectiva do homem enquanto elemento central em nosso ordenamento jurídico. Necessário, deste modo, resgatar as noções delineadas por Costas Douzinas acerca da utopia, elemento que deve nortear nosso anseio por mudança.

Como a realidade é sempre incompleta e o presente prenho de possibilidades futuras, todo realismo tem a utopia em seu centro. Utopia é o nome para o grande poder da imaginação que encontra o futuro latente em cada produto cultural e preserva o cerne do entusiasmo radical em toda ideologia que o critica. ${ }^{157}$

Reivindica-se, neste panorama, o real papel dos direitos humanos, traduzido no potencial de crítica e emancipação. Ainda nas palavras de Douzinas, "os direitos humanos representam a necessária e impossível reivindicação da lei à justiça. Eles extraem sua força do sofrimento do passado e das injustiças do presente e atuam como parasitas no corpo dos direitos, ao consumir o hospedeiro e projetar um futuro a partir de uma história jurídica um tanto insípida" ${ }^{\prime 58}$. Espera-se, nestes termos, uma rápida e real harmonização entre a LEP e os standards firmados pelo direito internacional dos direitos humanos no âmbito de proteção das crianças.

\footnotetext{
${ }^{155}$ FOUCAULT, Michel. Ditos e Escritos IV. Op. cit., p. 9.

${ }^{156}$ Ibid., p. 4.

${ }^{157}$ DOUZINAS, Costas. Op. cit., p. 189.

${ }^{158}$ Ibid., p. 383.
} 


\section{Referências Bibliográficas:}

ABRAMOVAY, Pedro Vieira. O grande encarceramento como produto da ideologia (neo)liberal. In: Depois do Grande Encarceramento. Rio de Janeiro: Editora Revan, 2010.

ADADD, Cristina; SANTOS, Maricy e NASCIMENTO, Tuane. Tempo de ser mãe: reflexões sobre a experiência da maternidade no sistema prisional do Estado do Rio de Janeiro. Diásporas, diversidade, deslocamentos, 23 a 26 de agosto de 2010. Disponível em: http://www.fazendogenero.ufsc.br/9/resources/anais/1278445643_ARQUI VO_Tempo_de_Ser_Mae.pdf. Acesso em: 01/11/14.

AGAMBEN, Giorgio. Homo Sacer: o poder soberano e a vida nua I. Belo Horizonte: Editora UFMG, 2002.

ALMEIDA, Angela Mendes de. Estado autoritário e violência institucional. In: Discursos Sediciosos, Ano 17. Números 19-20. Instituto Carioca de Criminologia. Rio de Janeiro: Editora Revan, 2012.

ALMEIDA, Sandra; MATTOS, Carmem, e ARAUJO, Adriane. Filhos e filhas de mulheres presas e vulnerabilidade socioeducacional: um estudo de abordagem etnográfica. VIII Encontro Nacional da ANDHEP, 2014. Disponível em: http://andhep.org.br/anais/arquivos/VIIIencontro/GT13.pdf. Acesso em: 01/11/14.

AZAMBUJA, Regina Fay. Os bebês filhos de mães que cumprem pena privativa de liberdade. Revista Gênero e Direito, 2013. ISSN 2179-7137. Disponível em: http://periodicos.ufpb.br/ojs/index.php/ged/article/view/16947/9647. Acesso em: 03/11/14. 
BATISTA, Nilo e ZAFFARONI, E. Raúl. Direito Penal Brasileiro, vol. I. Rio de Janeiro: Revan, 2003.

BATISTA, Vera Malaguti. Adeus às ilusões. Disponível em: https://www.academia.edu/4554263/Adeus_as_ilusoes. Acesso em: $30 / 10 / 14$.

Difíceis ganhos fáceis: drogas e juventude pobre no Rio de Janeiro. Rio de Janeiro: Instituto Carioca de Criminologia/Revan, 2003.

- Depois do grande encarceramento. In: BATISTA, Vera Malaguti e ABRAMOVAY, Pedro Vieira. Depois do Grande Encarceramento. Rio de Janeiro: Editora Revan, 2010.

BRASIL. Presidência da República. Secretaria Especial de Políticas para as Mulheres. Revista do Observatório Brasil da Igualdade de Gênero. Brasília: Secretaria Especial de Políticas para as Mulheres, 2009. Disponível em: http://www.mulheres.gov.br/mais-mulheres-nopoder/informacoes/materiais-diversos/revista_do_observatorio_bra.pdf. Acesso em: 01/11/14.

CARAZZAI, Estelita e CAMPANHA, Diogenes. Prisões brasileiras registram uma morte a cada dois dias. Folha de São Paulo online. Disponível em: http:/www1.folha.uol.com.br/cotidiano/2014/01/1395204prisoes-brasileiras-registram-uma-morte-a-cada-dois-dias.shtml. Acesso em: 21/07/14.

CEJIL. Relatório sobre as Mulheres Encarceradas no Brasil. Fevereiro de 2007. Disponível em: http://carceraria.org.br/wp- 
content/uploads/2013/02/Relatório-para-OEA-sobre-MulheresEncarceradas-no-Brasil-2007.pdf. Acesso em: 01/11/14.

\section{CHERNICHARO, Luciana; PENCIERI, Aline e SILVA, Bruna.} Mulheres encarceradas, seletividade penal e tráfico de drogas no Rio de Janeiro. VIII Encontro da ANDHEP, USP, São Paulo, 2014.

CHERNICHARO, L. A BOITEUX, L. Encarceramento feminino, seletividade penal e tráfico de drogas em uma perspectiva feminista crítica. Laboratório de Direitos Humanos/UFRJ.

CNJ. Novo diagnóstico de pessoas presas no Brasil. Aprovado em junho de 2014.

Disponível

em: http://www.cnj.jus.br/images/imprensa/pessoas_presas_no_brasil_final.pdf. Acesso em: 30/10/14.

CNPCP. Resolução número 03, de 15 de julho de 2009. Disponível em: http://www.google.com.br/url?sa=t\&rct=j\&q=\&esrc=s\&source=web\&cd=1 $\& v e d=0 \mathrm{CB} 0 \mathrm{QFjAA} \& u r l=\mathrm{http} \% 3 \mathrm{~A} \% 2 \mathrm{~F} \% 2 \mathrm{Fwww} \cdot$ defensoria.sp.gov.br\%2F dpesp\%2FRepositorio\%2F30\%2FDocumentos\%2FRESOLU\%25C3\%2587 $\% 25 \mathrm{C} 3 \% 2583 \mathrm{O} \% 2520 \mathrm{CNPCP} \% 2520 \mathrm{~N} \% 25 \mathrm{C} 2 \% 25 \mathrm{BA} \% 25203 \% 2 \mathrm{C} \% 2520$ DE\%252015\%2520DE\%2520JULHO\%2520DE\%25202009\%2520mulher \%2520encarcerada\%2520e\%2520filhos.doc\&ei=HvcyVLTtCYyrggTi1YH wCw\&usg=AFQjCNEjcEimDXLQRCpEuKdt37iPZ1APew\&sig2=dDZMe Qh6DXd82vfw6CNxZg\&bvm=bv.76802529,d.eXY. Acesso em: 06/10/14.

DORNELLES, João Ricardo W. Direitos humanos, violência e barbárie no Brasil: uma ponte entre o passado e o presente. In: ASSY, Bethania e DORNELLES, João Ricardo. Direitos humanos: justiça, verdade e memória. Rio de Janeiro: Lumen Iuris, 2012. 
DOUZINAS, Costas. O fim dos direitos humanos. São Leopoldo: Unisinos, 2009.

DARKE, Sacha e KARAM, Maria Lucia. Administrando o cotidiano da prisão no Brasil. In: Discursos Sediciosos, Ano 17. Números 19-20. Instituto Carioca de Criminologia. Rio de Janeiro: Editora Revan, 2012.

Fórum Econômico Mundial. Relatório e ranking do Global Gender Gap, 2013. Disponível em: http://www3.weforum.org/docs/Media/Portuguese_Gender\%20Gap_Final.p df. Acesso em: 01/11/14.

FOUCAULT, Michel. Vigiar e punir. Petrópolis: Editora Vozes, 1977. . Ditos e Escritos IV. Rio de Janeiro: Forense Universitária, 2010.

GIORDANO, Alberto. Ministério Público da Defesa da Argentina. Defensoria Geral da Nação. Comissão sobre Temáticas de Gênero. Disponível em:

http://www.mpd.gov.ar/articulo/downloadAttachment/id/2179. Acesso em: 04/11/14.

GOMES, Aline. As prisões do feminino e as mulheres nas prisões: um recorte sobre a maternidade encarcerada. Niterói, 2010. 111 p. Dissertação de mestrado - UFF.

GOMES, Aline; UZIEL, Anna Paula; SANTOS, Maricy e outras. Reflexões sobre a maternidade no sistema prisional: o que dizem técnicas e pesquisadoras. Convênio de Cooperação Técnica entre a UERJ e a SEAP/RJ.

Disponível 
em:http://www.abrapso.org.br/siteprincipal/images/Anais_XVENABRAPS O/366.\%20reflex\%D5es\%20sobre\%20a\%20maternidade\%20no\%20sistem a\%20prisional.pdf. Acesso em: 04/11/14.

INFOPEN. Relatório do Infopen de junho de 2011. Veiculado pelo Ministério da Justiça. Disponível em: http://portal.mj.gov.br/main.asp?View=\%7BDA8C1EA2-5CE1-45BDAA07-5765C04797D9\%7D\&BrowserType $=$ IE \&LangID $=$ ptbr\&params $=$ itemID $\% 3 \mathrm{D} \% 7 \mathrm{~B} 14 \mathrm{~A} 64773 \% 2 \mathrm{D} 0 \mathrm{CFB} \% 2 \mathrm{D} 45 \mathrm{~A} 4 \% 2 \mathrm{DBA} 6 \mathrm{~F} \%$ 2DEC41D9AFE2BB\%7D\%3B\&UIPartUID=\%7B2868BA3C $\% 2 \mathrm{D} 1 \mathrm{C} 72 \% 2$ D4347\%2DBE11\%2DA26F70F4CB26\%7D. Acesso em: 31/10/14.

. Sistema carcerário nacional tem apenas 15 ginecologistas para 35 mil mulheres presas. Veiculado pelo Ministério da Justiça, dezembro de 2012. Disponível em: http://www.cnj.jus.br/noticias/cnj/25949:sistemacarcerario-nacional-tem-apenas-15-ginecologistas-para-35-mil-mulherespresas. Acesso em: 09/10/14.

JABARDO, Mercedes. La mujer y sus hijos en prision. IN: Eguzkilore. Número 7. San Sebastián, 1993. Disponível em: http://www.ehu.es/documents/1736829/2169056/10+$+\mathrm{La}+$ mujer+y+sus+hijos+en+prision.pdf. Acesso em: 03/11/14.

LOPES, Juliana. Letalidade seletiva e exceção: a política de segurança pública do Rio de janeiro. Rio de Janeiro. 2013. Dissertação de mestrado. Faculdade de direito - Departamento de Direito da PUC-Rio.

LOPEZ, Marcela Briseño. Garantizando los derechos humanos de las mujeres en reclusión. Instituto Nacional de las Mujeres do México e Programa das Nações Unidas para o Desenvolvimento (PNUD), 2006. Disponível em: 
http://cedoc.inmujeres.gob.mx/documentos_download/100793.pdf. Acesso em: $01 / 11 / 14$.

LORA, Laura Noemí. Niños y madres que permanecen en establecimientos carcelarios: escenarios de conflito. XII Jornadas Nacionales de Filosofía y Ciencias Políticas. Universidad Nacional de Mar del Plata, Facultad de Derecho, 2012. Disponível em: http://www.derecho.uba.ar/investigacion/investigadores/publicaciones/loraninos-y-madres-que-permanecen-en-establecimientos-carcelariosescenarios-de-conflicto.pdf. Acesso em: 02/11/14.

MACHADO, Juliana Araújo. A presa gestante ou lactante tem direito a prisão domiciliar especial quando não houver vaga em estabelecimento penal adequado. Defensoria Pública do Estado de São Paulo. Disponível em:http://www.cursofmb.com.br/arquivosprof/gestante $\% 20 \mathrm{e} \% 20$ prisão\%20 domiciliar.pdf. Acesso em: 27/10/2014.

MARIZ, Renata. Dúvida sobre o período que um bebê pode ficar com a mãe na cadeia sem prejuízo à criança persiste. Correio Braziliense Online, publicado em 10 de agosto de 2010, p. 1. Disponível em:

http://www.correiobraziliense.com.br/app/noticia/brasil/2010/08/10/interna _brasil,206879/index.shtml. Acesso em: 01/11/14.

\section{MATTOS, Carmen Guimarães de; MACIEL, Sandra e CASTRO,}

Paula Almeida de. Educação e vulnerabilidade: um estudo etnográfico com jovens e mulheres em privação de liberdade. Revista Eletrônica de Educação, maio de 2013. Disponível em: http://www.reveduc.ufscar.br/index.php/reveduc/article/viewFile/615/231. Acesso em: 04/11/14. 
NUSPEN. Procedimento Especial apresentado pelo Núcleo do Sistema Penitenciário da Defensoria Pública do Estado do Rio de Janeiro à VEP no dia 09/11/2012. Protocolo VEP: 2012/0181213-6.

OEA. Convenção Americana sobre Direitos Humanos. Assinada em 22 de novembro de 196

. Declaração Americana dos Direitos e Deveres do Homem. Aprovada em 1948.

- Convenção Interamericana para Prevenir, Punir e Erradicar a Violência contra a Mulher. Adotada em Belém do Pará, Brasil, em 09 de Junho de 1994.

. Corte Interamericana de Direitos Humanos. Medida Provisória. Caso da Penitenciário Urso Branco. Disponível em: http://www.oas.org/pt/. Acesso em: 29/09/2014.

- Corte Interamericana de Direitos Humanos. Condición Jurídica y Derechos Humanos del Niño. Opinião Consultiva OC-17/02 de 28 de agosto de 2002. Serie A No. 17.

. Comissão Interamericana de Direitos Humanos. Medida Cautelar. Caso do Complexo Penitenciário de Pedrinhas. Disponível em: http://www.oas.org/pt/. Acesso em: 29/09/2014.

. Comissão Interamericana de Direitos Humanos. Direito da Criança à Família. Cuidado Alternativo. Ponto fim à Institucionalização nas Américas. Aprovado em 17 de outubro de 2013. Disponível em: http://www.oas.org/es/cidh/infancia/docs/pdf/Informe-derecho-nino-afamilia.pdf. Acesso em: 01/11/14. 
. Comissão Interamericana de Direitos Humanos. Justicia juvenil y derechos humanos en las Américas. Aprovado em 13 de julho de 2011. Disponível em: http://www.oas.org/es/cidh/infancia/docs/pdf/JusticiaJuvenil.pdf. Acesso em: 01/11/14.

ONU. Convenção sobre os Direitos das Crianças. Adotada pela Assembleia Geral das Nações Unidas em 20 de novembro de 1989.

. Comitê dos Direitos das Crianças. Observação Geral n. 5. Medidas generales de aplicación de la Convención sobre los Derechos del Niño. Aprovada em outubro de 2003.

. Comitê dos Direitos das Crianças. Examen de los Informes Enviados por los Estados Partes en virtud del artículo 44 de la Convención sobre los Derechos del Niño. Observaciones finales: Tailandia, Informe $\mathrm{CRC} / \mathrm{C} / \mathrm{THA} / \mathrm{CO} / 2$.

. Comitê dos Direitos das Crianças. Examen de los Informes Enviados por los Estados Partes en virtud del artículo 44 de la Convención sobre los Derechos del Niño, Observaciones finales: Nepal, CRC/C/15/Add.261, $21 / 09 / 2005$.

. Comitê Direitos Econômicos Sociais e Culturais. Observação Geral n. 14. Aprovada no 22 período de Sessões das Nações Unidas em 2000. . Regras de Bangkok. Adotada pela Assembleia Geral em 16/03/11. Resolução A/RES/65/229. Disponível em: https://www.unodc.org/documents/commissions/CCPCJ/Crime_Resolution 
s/2010-2019/2010/General_Assembly/A-RES-65-229.pdf. Acesso em: 03/11/14.

- Regras Mínimas para o Tratamento dos Reclusos. Adotadas pelo Primeiro Congresso das Nações Unidas sobre a Prevenção do Crime e o Tratamento dos Delinquentes, em 1955. Resolução 663 C (XXIV) do Conselho Econômico e Social.

PLASTINO, Carlos Alberto. Vida, criatividade e sentido no pensamento de Winnicott. Rio de Janeiro: Garamond, 2014.

RODRIGUEZ, Marcela. Câmara de Deputados Argentina. 22 Reunião da 14 Sessão Ordinária. Disponível em: http://www1.hcdn.gov.ar/sesionesxml/item_param.asp?per=125\&r=22\&n= 20\&orador=RODRIGUEZ\&nombres=MARCELA\%20VIRGINIA. Acesso em: 04/11/14.

ROSA, João Guimarães Rosa. Grande sertão: veredas. Rio de Janeiro: Nova Fronteira, 2001.

SANTOS, Boaventura de Sousa. Se Deus Fosse um Activista dos Direitos Humanos. Coimbra: Edições Almedina, S.A., 2013.

SANTOS, Raquel. Maternidade no cárcere: Reflexões sobre o Sistema Penitenciário Feminino. Niterói. 2011. Dissertação de mestrado. Mestrado em Política Social - Escola de Serviço Social UFF.

SEAP/RJ. Coordenação de Gestão em Saúde Penitenciária. Saúde da Mulher-Protocolo Gestante, 2013. 
SIMONE, Vanessa Fusco Nogueira. Filhos do cárcere: limites e possibilidades de garantir os direitos fundamentais dos filhos das mulheres privadas de liberdade no Brasil. Porto Alegre: Núria Fabris, 2013.

STJ. HC. 115.941/PE, Rel. Ministra Maria Thereza de Assis Moura, Brasília, 03/08/09.

UNICEF. Escirtório da Argentina. Mujeres presas: la situación de las mujeres embarazadas o con hijos/as menores de edad. Edição de out. de 2008.

Disponível

em:

http://www.unicef.org/argentina/spanish/Libro_Mujeres_Presas.pdf. Acesso em: 10/10/14.

UZIEL, Anna Paula (org.). Maternidade e Sistema Penitenciário. Convênio de Cooperação Técnica SEAP-UERJ. Edital CNPq: 57/2008; Processo: 402728/2008-4.

PRATES, Maria Clara; MELLO, Alessandra e outra. Filhos do cárcere. Correio Brasiliense Online, 11 dezembro de 2011. Disponível em: http://cnj.myclipp.inf.br/default.asp?smenu=noticias\&dtlh=204957\&iABA $=$ Not $\%$ EDcias\&exp. Acesso em: 06/10/14.

WACQUANT, Loïc. Punir os pobres. Rio de Janeiro: Editora Revan, 2007.

WINNICOTT, Donald W. Os bebês e suas mamães. Tradução de CAMARGO, Jefferson Luiz. 3 edição. São Paulo: Martins Fontes, 2006.

ZAFFARONI, E. Raúl. $O$ inimigo no direito penal. Rio de Janeiro: Editora Revan, 2007. 
Derecho Penal, Parte General. Buenos Aires:

Ediar Sociedad Anónima Editora, Comercial, Industrial y Financiera, 1999.

\section{Entrevistas extraídas de arquivos digitais:}

BATISTA, Nilo. In: Revista Poli. Entrevista: Nilo Batista - 'Muita Pena sinaliza pouco oxigênio Democrático, sinaliza autoritarismo'. Edição n. 29, de jul/ago. 2013.2 Disponível em: http://www.epsjv.fiocruz.br/upload/EdicoesRevistaPoli/R36.pdf. Acesso em: 20/07/14.

LEMGRUBER, Julita. In: MONTENEGRO, Manuel Carlos. População Carcerária feminina aumenta $42 \%$ nos últimos cinco anos. CNJ Online. Disponível em: http://www.cnj.jus.br/noticias/cnj/25998-populacaocarceraria-feminina-aumenta-42-nos-ultimos-cinco-anos\#ad-image-0. Acesso em: 03/11/14.

VITTO Renato de. In: RECONDO, Felipe. Prisões batem novo recorde de lotação. JusBrasil, 2014. Disponível em: http://temistoclestelmo.jusbrasil.com.br/noticias/147934768/prisoes-batemnovo-recorde-de-lotacao. Acesso em: 01/11/14.

RITA, Rosângela Santa. In: ROMERO, Thiago. Infância comprometida. FAPESP Online. Disponível em: http://agencia.fapesp.br/infancia_comprometida/6623/. Acesso em: $01 / 11 / 14$. 